\title{
Fiscal Year 1997-1998 Waste Information Requirements Document
}


LEGAL DISCLATMER

This report was prepared as an account of work sponsored by an agency of the United States Government. Neither the United States Government nor any agency thereof, nor any of their employees, nor any of their contractors, subcontractors or their employees, makes any warranty, express or implied, $\alpha$ assumes any legal liability or responsibility for the accuracy, completeness, or any third party's use or the results of such use of any information, apparabus, product, or process disclosed, or represents that its use would not infringe privately owned rights. Reference herein to any specific commercial product, process, or service by trade name, trademark, maxufacturer, or therwise, does not necessarily constiture or imply its endorsement, recommendation, or fawring by the United States Govermment or any agency thereof or its cortractors or subcontractors. The views and opirions of authors expressed herein do not pecessarily state or reflect those of the United States Govemmert or any agency thereof.

This report has been reproctuced from the best available copy. Available in paper copy and microfiche.

Available to the U.S. Department of Energy

and its cortractors from

Office of Scientific and Techrical Information

P.O. Box 62

Oak Ridge, TN 37831

(615) $576-8401$

Available to the public from the U.S. Department of Commerce National Techrical Information Service

5285 Pon Royal Road

Springfield, VA 22161

(703) $487-4650$

Prirted in the United States of America

DISCLM-1.CHP (1-91) 


\section{RELEASE AUTHORIZATION}

Document Number: $\quad$ DOE/RL-97-76

Document Title: $\quad$ Fiscal Year 1997-1998 Waste Information Requirements Document

Release Date: $\quad 9 / 5 / 97$

This document was reviewed following the procedures described in WHC-CM-3-4 and is:

APPROVED FOR PUBLIC RELEASE

WHC Information Release Administration Specialist:

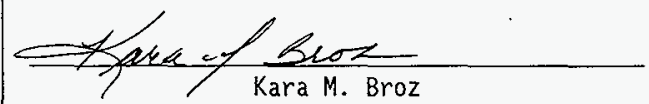

September 5, 1997 


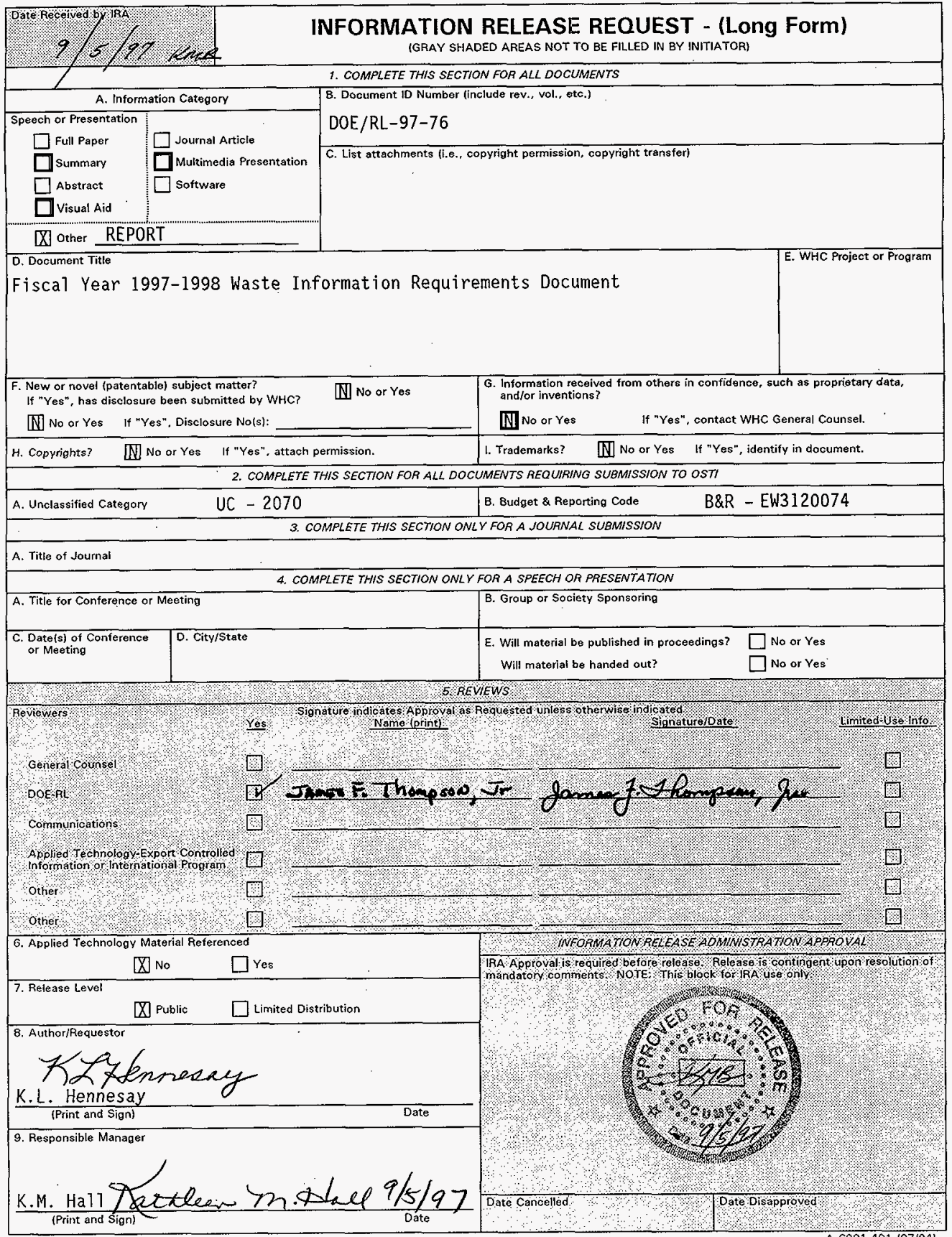


DOE/RL-97-76

Document ID Number

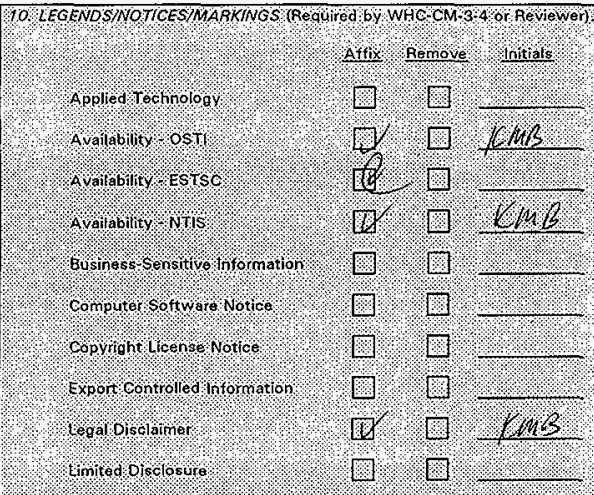

\section{MANDATORY COMMENTS IL TS only mand a to r comments here:

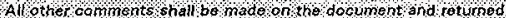
to the author

otficial use only

Patent status

Predecisionat normation

Prooraningtio Noticc

Propitetary thotrut tion

Rurpose and $\mathrm{Use}$

Thesis/Oissertetion

Trademark Discloiner

other?

Afix Bemove 1 nitials

12?

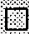

s.

2

1

ro

1

.

\$12\%

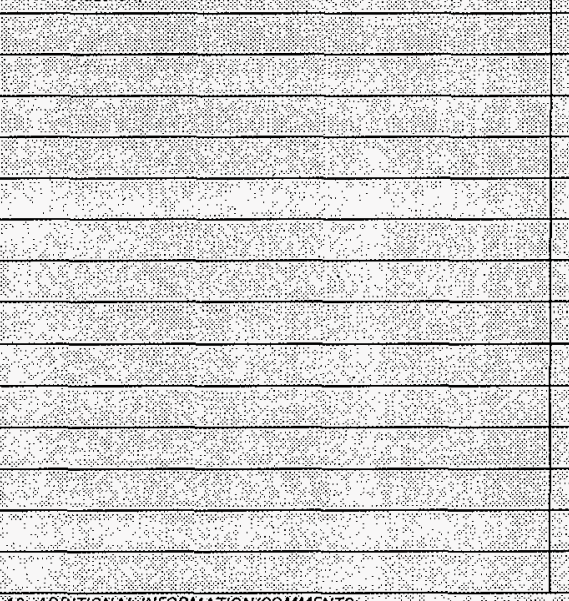

Reviewer IPrint\& Sign

\section{Date:}

Resolved by Author/Requestor (Print \& Sign) 


\section{CONTENTS}

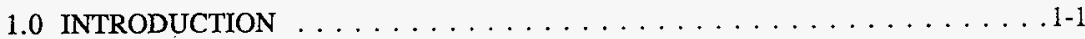

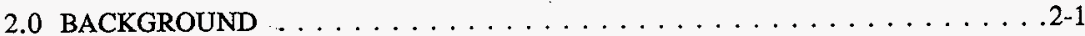

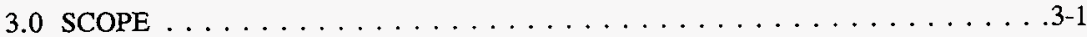

4.0 TANK WASTE REMEDIATION SYSTEM DRIVERS WHICH REQUIRE CHARACTERIZATION INFORMATION $\ldots \ldots \ldots \ldots \ldots \ldots . . \ldots .4$ 4.1 PRIMARY TANK WASTE REMEDIATION SYSTEM DRIVERS REQUIRING CHARACTERIZATION INFORMATION . . . . . . . 4-2

4.1.1 Tri-Party Agreement Milestones . . . . . . . . . . . . 4-2

4.1.2 Defense Nuclear Facilities Safety Board Recommendation 93-5 Implementation Plan . . . . . . . . . . . . . . . . . . . 4-4

4.1.3 Regulatory Drivers to Characterization . . . . . . . . 4-5

4.1.4 Department of Energy Directions . . . . . . . . . . 4-5

4.1 .5 Authorization Basis . . . . . . . . . . . . . . . . .5

4.2 SUPPORTING INFORMATION FOR DRIVERS . . . . . . . . . . 4-5

4.2.1 Tank Waste Remediation Data Quality Objectives . . . . . . . . 4-6

4.2 .2 Evaporator Operations . . . . . . . . . . . . . 4-6

4.2.3 Tank Waste Remediation System Topical Reports . . . . . . . . 4-6

4.2.4 Tank Characterization Technical Sampling Basis . . . . . . . . 4-6

4.2.5 Characterization Sampling Schedule . . . . . . . . . . 4-7

5.0 TANK WASTE REMEDIATION SYSTEM ISSUES WITH

CHARACTERIZATION INFORMATION REQUIREMENTS $\ldots \ldots \ldots \ldots .5$. . . .

5.1 INFORMATION REQUIREMENTS AND ISSUES . . . . . . . . . . 5-2

5.1 .1 Safety Issue Resolution . . . . . . . . . . . . . . . 5-2

5.1 .2 Operations and Maintenance $\ldots \ldots \ldots \ldots \ldots \ldots \ldots \ldots$

5.1 .3 Disposal . . . . . . . . . . . . . . . . . . . . . 5-7

5.1.4 Characterization for Historical Data Evaluation . . . . . . . . 5-9

5.1 .5 Regulatory Compliance Issues . . . . . . . . . . . 5-10

5.2 ISSUE PRIORITIZATION AND TECHNICAL SAMPLING BASIS $\ldots .5$ 5-10

5.3 ASSUMPTIONS AND BASIS FOR WORK ESTIMATES . . . . . . . 5-11

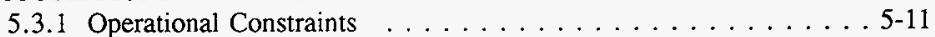

5.3.2 Deliverable Time Requirements . . . . . . . . . 5-13

6.0 INFORMATION REQUIREMENTS MATRIX . . . . . . . . . . 6-1

6.1 INFORMATION REQUIREMENTS MATRIX CONTENT . . . . . . . . 6-1

6.2 SUMMARY DISCUSSION OF INFORMATION REQUIREMENTS . . . 6- 6-15

6.2.1 Summary Characterization Project Sampling Events . . . . . . 6-15

6.2 .2 Summary Characterization Reports . . . . . . . . 6-15 


\section{CONTENTS (Continued)}

7.0 DESCRIPTION OF CHARACTERIZATION PROJECT DELIVERABLES

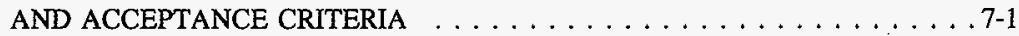

7.1 CHARACTERIZATION PROJECT SAMPLING ACTIVITIES . . . . . . 7-1

7.1 .1 Core Samples . . . . . . . . . . . . . . . 7-1

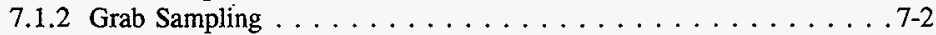

7.1 .3 Vapor Sampling . . . . . . . . . . . . . . .7-2

7.1 .4 Auger Sampling . . . . . . . . . . . . . . . . 7-2

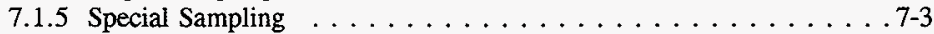

7.2 CHARACTERIZATION PROJECT REPORTS $\ldots \ldots \ldots \ldots \ldots \ldots .7-3$

7.2.1 Laboratory Analysis Reports . . . . . . . . . . . . . 7-3

7.2.2 Tank Characterization Reports . . . . . . . . . . . 7-3

7.2 .3 Data Quality Objectives ... . . . . . . . . . . . . 7-4

7.2.4 Historical Tank Content Estimates . . . . . . . . . . . 7-4

7.2 .5 Best Basis Inventory Reports . . . . . . . . . . . . . . 7-5

7.2.6 Vapor Space Phenomenology Reports . . . . . . . . . . . 7-5

7.2.7 Tank by Tank Safety Evaluation . . . . . . . . . . . 7-5

7.2.8 High-Priority Tank Evaluation . . . . . . . . . . . . 7-5

7.3 ACCEPTANCE CRITERIA FOR ECOLOGY DELIVERABLES $\ldots \ldots \ldots 7-6$

7.3.1 Waste Information Requirements Document . . . . . . . . . 7-6

7.3.2 Tank Characterization Reports . . . . . . . . . . . 7-7

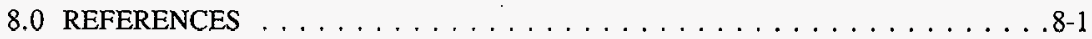

\section{APPENDIXES}

A TRI-PARTY AGREEMENT NUMBERS AND TITLES $\ldots \ldots \ldots \ldots \ldots \ldots$ A-1

B DEFENSE NUCLEAR FACILITIES SAFETY BOARD MILESTONE

NUMBERS AND TITLES $\ldots \ldots \ldots \ldots \ldots \ldots \ldots$ B-1 
DOE/RL-97-76 Rev, 0

\section{LIST OF TABLES}



6-2 Opportunistic Information Drivers $\ldots \ldots \ldots \ldots \ldots \ldots$ 6-13

6-3 Summary of Characterization Project Sampling Events $\ldots \ldots \ldots \ldots \ldots$ 6-15

6-4 Summary of Characterization Project Reports . . . . . . . . . . 6-16 


\section{LIST OF TERMS}

Btu/hr
DNFSB
DOE-RL
DQO
DST
Ecology
EPA
FY
HLW
HPT
HTCE
HTI
ISB
ISVS
J/g
LAW
LDUA
LHMC
RGS
RMCS
SST
TCR
TOC
TWRS
USQ
VSS
WIRD

British thermal units per hour Defense Nuclear Facilities Safety Board U.S. Department of Energy, Richland Operations Office data quality objective double-shell tank Washington State Department of Ecology U. S. Environmental Protection Agency fiscal year high-level waste high priority tank historical tank content estimate Hanford Tanks Initiative Interim Safety Basis in-situ vapor sampling joules per gram low activity waste light duty utility arm Lockheed Martin Hanford Corporation retained gas sampler rotary mode code system single-shell tank tank characterization report total organic carbon Tank Waste Remediation System unreviewed safety question vapor sampling system Waste Information Requirements Document 


\subsection{INTRODUCTION}

The Waste Information Requirements Document describes the activities of the Tank Waste Remediation System (TWRS) Characterization Project that provide characterization information on Hanford Site waste tanks. The characterization information is required to perform operations and meet the commitments of TWRS end users. These commitments are derived from the Hanford Federal Facility Agreement and Consent Order (Ecology et al. 1996), also known as the Tri-Party Agreement; the Recommendation 93-5 Implementation Plan (DOE-RL 1996) to the Defense Nuclear Facilities Safety Board (DNFSB); and other directives as listed in Section 4.0.

This Waste Information Requirement Document applies to Fiscal Years 1997 and 1998 activities. Its contents are based on the best information available in August 1997. The format and content are based on the directions of DOE-RL (Sieracki 1997) and Fluor Daniel Hanford Incorporated (Umek 1997). Activities, such as the revision of the Tank Characterization Technical Sampling Basis (Brown et al. 1997), the revision of the data quality objectives.(DQOs), issue closures, discussions with Ecology, and management decisions may cause subsequent updates to the Waste Information Requirements Document. 
This page intentionally left blank. 


\subsection{BACKGROUND}

The Hanford Federal Facility Agreement and Consent Order (Tri-Party Agreement), Milestone M-44-00 required the sampling of all tanks and the development of Tank Characterization Reports. (TCRs) as deliverables. This milestone intended that the TCRs would be used by Ecology to measure the progress of the Characterization Project in meeting the information requirements of the Tank Waste Remediation System (TWRS).

It became apparent that this process did not effectively tie characterization activities to program needs. Therefore, a team composed of Ecology, DOE-RL, and contractor personnel, including Fluor Daniel Hanford Incorporated and Lockheed Martin Hanford Corporation, was formed to address the issue of how to tie characterization activities to program needs. The team efforts resulted in the need to construct the Waste Information Requirements Document.

The Waste Information Requirements Document and its updates will replace the tank waste analysis plans and the Tank Characterization Plan requirements of the Tri-Party Agreement, Milestone $M-44-01$ and $M-44-02$ series. Past tank waste analysis plans only addressed the TCRs to be produced in the next fiscal year on tanks without existing TCRs. The Waste Information Requirements Document will address all Characterization Project deliverables as well as TCRs that support TWRS objectives. 
This page intentionally left blank. 


\subsection{SCOPE}

The Waste Information Requirements Document describes the activities of the TWRS Characterization Project for meeting the characterization information requirements of the Hanford Site waste tanks. The document eventually will integrate TWRS deliverables requiring the characterization of, or information on, tank waste behavior between Fiscal Years 1997 and 2002 where the Characterization Project is responsible for supplying sample material, analyses, and/or other forms of tank waste information such as reports and studies. This document presents this information for Fiscal Year 1997 and 1998. Out year information will be included in future releases of the Waste Information Requirements Document.

This Fiscal Year 1997-1998 Waste Information Requirements Document is limited to completing Phase A of the Waste Information Requirements Document (Umek 1997). It will include a matrix listing of Characterization Project deliverables for Fiscal Years 1997 and 1998 and a text description. Phase B, to be conducted in Fiscal Year 1998, is intended to expand the matrix of deliverables through Fiscal Year 2002 or beyond. It is intended that deliverables and associated milestones will be evaluated during Phase B for validity, omissions, overlaps, or additions. In subsequent years, the Waste Information Requirements Document will be updated annually. 
This page intentionally left blank. 


\subsection{TANK WASTE REMEDIATION SYSTEM DRIVERS WHICH REQUIRE CHARACTERIZATION INFORMATION}

Tank Waste Remediation System program drivers are derived from the following primary sources: Tri-Party Agreement milestones, DNFSB recommendations, DOE-RL directions, regulatory drivers, and the Authorization Basis (see Section 4.1.5). Documents describing these drivers, program activities meeting the objectives of the drivers, and associated information needs were used to provide input to the Waste Information Requirements Document. In developing the Fiscal Year 1998 document, a limited but reasonably complete literature survey was conducted to identify TWRS milestones and drivers that require tank waste characterization information and waste behavior information for the solid, liquid, and vapor phases of tank wastes. The information was used to develop a matrix of Characterization Project deliverables in support of the TWRS milestones and/or drivers along with deliverable due dates by the fiscal year required to support TWRS milestone completion (see Section 6.0).

Documents used in the Waste Information Requirements Document have been divided into primary drivers and supporting information for drivers. Primary drivers include the following.

- Hanford Federal Facility Agreement and Consent Order (Tri-Party Agreement)

- DNFSB Recommendation 93-5 Implementation Plan

- Regulatory drivers

- DOE-RL directions

- Authorization Basis

Supporting information includes the following.

- Privatization project mid-level logic

- Evaporator campaign schedules

- $\quad$ All TWRS DQOS

- TWRS topical reports that result or will result in waste phenomena and/or waste behavior studies

- Characterization technical sampling basis

- Characterization sampling schedule. 
Each primary driver and supporting item of information is discussed in the sections below. Of the five primary drivers listed, only the Tri-Party Agreement, DNFSB, and regulatory drivers are in scope of the Phase A Waste Information Requirements Document. The two remaining primary drivers are included because some support documentation (in Phase A) and current characterization activities are linked to these drivers.

\subsection{PRIMARY TANK WASTE REMEDIATION SYSTEM DRIVERS REQUTRING CHARACTERIZATION INFORMATION}

Each major TWRS program milestone is classified according to its source.

\subsubsection{Tri-Party Agreement Milestones}

The Tri-Party Agreement is an agreement between the U.S. Department of Energy, Washington State Department of Ecology, and the United States Environmental Protection Agency. The agreement defines what actions the Department of Energy or it contractors must take to support the cleanup mission at the Hanford Site. The milestones in the Tri-Party Agreement constitute a major driver for characterization activities. Seven major Tri-Party Agreement milestones are supported by the Characterization Project. These are M-40-00, M-41-00, M-44-00, M-45-00, M-50-00, M-51-00, and M-60-00. Each milestone includes interim milestones. Appendix A lists Tri-Party Agreement milestone numbers and titles.

4.1.1.1 Tri-Party Agreement Major Milestone M-40-00. Tri-Party Agreement Milestone M-40-00 deals with closing all safety issues associated with single-shell and double-shell tanks. The Characterization Project supports completing this milestone through the sampling and analysis of tank waste material. Each safety issue has an associated DQO that specifies what information is required to resolve the safety issue.

4.1.1.2 Tri-Party Agreement Major Milestone M-41-00. Tri-Party Agreement Milestone M-41-00 deals with the stabilization of single-shell tanks. This involves removing the pumpable liquid from the tanks and moving it to receiving double-shell tanks. This operation requires compatibility analysis on the tank liquid to be stabilized and the receiving tank. The Characterization Project supports this major Tri-Party Agreement milestone by compatibility sampling and analysis.

4.1.1.3 Tri-Party Agreement Major Milestone M-44-00. Tri-Party Agreement Milestone M-44-00 currently requires the Project Management Hanford Contractor to "ISSUE TANK CHARACTERIZATION REPORTS BASED ON PROCESS KNOWLEDGE, PRIOR CHARACTERIZATION DATA, AND VALIDATED EMPIRICAL DATA ACQUIRED AFTER MAY 1989 FOR 177 HANFORD HIGH-LEVEL WASTE (HLW) TANKS. PROVIDE OFFSITE ACCESS TO DATABASES. " 
Interim milestones associated with M-44-00 currently include M-44-10, M-44-11, and M-44-12 which define the number of TCRs to be produced in a fiscal year on tanks which have been newly sampled and do not have an existing TCR.

Tri-Party Agreement milestone M-44 is being rewritten. The rewritten milestone is expected to result in the Waste Information Requirements Document submitted annually to Ecology, issuance of all deliverable identified in the Waste Information Requirements Document, and entry of characterization information into an electronic database.

4.1.1.4 Tri-Party Agreement Major Milestone M-45-00. Milestone M-45-00 directs the closure of all single-shell tank farms. Closure of a single-shell tank follows the retrieval of as much tank waste as technically possible. Characterization support of this milestone will start during the sluicing of tank 241-C-106. Further characterization support of Milestone M-45-00 will be provided when the Hanford Tanks Initiative begins its effort to bring closure to one tank and to develop technology to bring closure to other tanks.

4.1.1.5 Tri-Party Agreement Major Milestone M-50-00. Milestone M-50-00 requires the completion of pretreatment processing of Hanford Site tank waste. Before waste is pretreated, sludge washing and sludge pretreatment methods will be evaluated to determine whether these processes will be capable of satisfying set criteria for pretreatment.

Characterization is supporting this evaluation of pretreatment methods by supplying the pretreatment program with tank samples.

4.1.1.6 Tri-Party Agreement Major Milestone M-51-00. Milestone M-51-00 directs the vitrification of Hanford Site HLW. Although the sub-milestones under milestone M-51-00 were written to an older strategy for processing HLW, milestone M-51-00 is still the primary driver of HLW vitrification. Contracts DE-RP06-96RL13308 and DE-RP06-96RL13309 between the Department of Energy and two private vendors were written so that vendors could support the vitrification effort. This effort is referred to as privatization. The Department of Energy is required to supply the private vendors with waste samples and characterization support as necessary. Characterization support for the privatization effort is defined in the mid-level logic (Hall 1997).

4.1.1.7 Tri-Party Agreement Milestone M-60-00. Milestone M-60-00 directs the vitrification of Hanford Site low-activity waste (LAW). Many sub-milestones under milestone M-60-00 were renegotiated to reflect the new privatization strategy for LAW vitrification. Contracts DE-RP06-96RL13308 and DE-RP06-96RL13309 between the Department of Energy and two private vendors were written so that vendors could support the vitrification effort (privatization). The Department of Energy is required to supply the private vendors with waste samples and characterization support as necessary. Characterization support for the privatization effort is defined in the mid-level logic (Hall 1997). 


\subsubsection{Defense Nuclear Facilities Safety Board Recommendation 93-5 Implementation Plan}

On July 19, 1993, the DNFSB transmitted Recommendation 93-5 (Conway 1993) to the Department of Energy. Recommendation 93-5 identified two general issues:

- Insufficient tank waste technical information exists, and the pace of acquiring additional information is too slow to ensure that wastes can be safely. stored and that operations can be conducted safely, and

- Insufficient tank waste technical information exists, and the pace of acquiring additional information is too slow to ensure that future disposal program data requirements can be met.

In response to Board recommendations, the Department of Energy issued the Recommendation 93-5 Implementation Plan, Rev. 1 (DOE-RL 1996). Revision 1 identifies actions to be taken by TWRS to ensure that safety and disposal programs obtain the necessary technical information to perform their functions and that the Characterization Project responds to the needs of the safety and disposal programs. The titles of DNFSB milestone commitments being supported in Fiscal Year 1997 and 1998 can be found in Appendix B. These actions are summarized below.

\subsubsection{Safe Storage of Tank Wastes and Safe Operation of Tank Farms. DOE-RL} (1996) identified several milestones to accelerate the resolution of the tank safety issues and to ensure safe operations in TWRS (see Section 5.4.3). Safe operations in TWRS are enhanced by upgrading the Authorization Basis, including completion of the Basis for Interim Operations and the Final Safety Analysis Report. Milestones related to upgrading the Authorization Basis are listed in Section 5.4.3.1 of DOE-RL (1996). The identified safety issues included ferrocyanide, organic complexants, organic solvents, flammable gas, high heat, and criticality. Milestones supporting the resolution of these safety issues are listed in Sections 5.4.3.2 through 5.4.3.7 of the plan.

4.1.2.2 Disposal Program Data Requirements. Characterization support for the disposal program consists primarily of supplying waste samples for process testing. The disposal program has identified high-priority tanks for sampling. Section 5.5.6.1 of DOE-RL (1996) gives the milestone to support characterization of the disposal high-priority tanks.

4.1.2.3 Technical Basis for Characterization. The implementation plan identified the need to increase the sampling efforts of the Characterization Project. More sampling is required as well as an increased focus on the sampling tanks that are going to yield a higher return of information to safety and disposal programs. Section 5.6.3.1. of DOE-RL (1966) lists the milestones to drive the improved characterization of tank waste. 


\subsubsection{Regulatory Drivers to Characterization}

Several state and federal regulatory requirements are associated with sampling and analysis of waste effluents and air emissions under the jurisdiction of TWRS. Characterization activities supporting regulatory requirements have been identified in the Tank Characterization Technical Sampling Basis (Brown et al. 1997) and will be listed in this report. Regulatory drivers are listed in Mulkey (1996) and Mulkey and Markillie (1995).

\subsubsection{Department of Energy Directions}

Although DOE-RL milestones were not intended to be included in Phase A of the Waste Information Requirements Document, some characterization activities defined in the Tank Characterization Technical Sampling Basis (Brown et al. 1997) are driven by DOE-RL milestones. These milestones will be listed in this document. Future revisions of this document will include an evaluation of DOE-RL milestone drivers and subsequent Characterization Project activities to support them.

\subsubsection{Authorization Basis}

The Hanford Site Tank Interim Safery Basis (ISB) (Stahl 1997) provides a reference to the tank farms safety envelope (commonly referred to as Authorization Basis). The safety envelope constitutes the technical basis for safe operation and maintenance of the tank farm facilities, equipment, and processes. The ISB is intended to facilitate understanding of the safety envelope and its corresponding justification until the Final Safety Analysis Report can be completed in accordance with recently issued DOE requirements. Conditions which exist outside of the Authorization Basis require the issuance of USQ documentation. The USQs require the acquisition or analysis of data to determine its status and need for more information. The ISB is used as the primary reference for all USQ evaluations.

In addition, the ISB and applicable operating safety documents provide the basis for the caustic mitigation issue. Tank waste sampling and analysis is required when it is believed that waste may be outside the limits imposed by operating safety documents (LMHC 1996).

\subsection{SUPPORTING INFORMATION FOR DRIVERS}

Supporting information for the primary drivers helps direct the way in which the TWRS program addresses them. 


\subsubsection{Tank Waste Remediation Data Quality Objectives}

The DQOs define the work scope required to address a specific issue and contain guidance on the type and extent of characterization necessary to address those issues. Each TWRS program issue has an associated DQO that defines questions, required information and the quality of information required to address questions.

\subsubsection{Evaporator Operations}

Evaporator operations minimize the waste volume stored in double-shell tanks. Operations depend on having sufficient slurry feed available for an efficient campaign. The primary source of slurry feed is liquid pumped from the single-shell tanks being interim stabilized. Waste generated at the 222-S Laboratory and at T-Plant are also sources of slurry feed for the evaporator. To meet the environmental and operational constraints of the evaporator safety basis, samples must be taken and analyzed from the slurry feed tanks.

\subsubsection{Tank Waste Remediation System Topical Reports}

Topical reports that result or will result in waste phenomena and/or waste behavior studies discuss and evaluate the current knowledge on a particular issue. As a result, additional data or analysis needs could be discovered. These reports are included to cover these types of drivers.

Although several topical reports have been written on safety issues, only the flammable gas topical report is for a program still requiring new information. There are no specific additional data requirements identified from the flammable gas topical report. The organic topical report is in the process of being issued. Additional requirements from this report will be included in future revisions of the Waste Information Requirements Document.

\subsubsection{Tank Characterization Technical Sampling Basis}

The Tank Characterization Technical Sampling Basis (Brown et al. 1997) establishes priorities for sampling and characterization activities for the TWRS Characterization Project. The sampling basis integrates the information needed to address safety issues, disposal projects, and historical model evaluation issues. 


\subsubsection{Characterization Sampling Schedule}

Although the Baseline Sampling Schedule. Change 97-01 (Stanton 1997) is not a program driver, it does indicate the number of samples and type of samples that can be obtained each fiscal year. The schedule uses the sampling priority developed in the Characterization Sampling Basis (Brown et al. 1997) and operational availability to schedule tank sampling events. 
This page intentionally left blank. 


\subsection{TANK WASTE REMEDIATION SYSTEM ISSUES WITH CHARACTERIZATION INFORMATION REQUIREMENTS}

There are five primary drivers of Characterization Project information requirements: 1) commitments to the Hanford Federal Facility Agreement and Consent Order (Tri-Party Agreement) (Ecology et al. 1996), 2) commitments to the DNSFB contained in DOE-RL (1996), 3) directions from DOE-RL, 4) regulatory drivers, and 5) the Authorization Basis. These sources provide the requirements and issues to be addressed by the TWRS project:

These commitments have been divided into the following activity categories:

- Safety issue resolution

- Operations and maintenance including process operations, compatibility, and evaporator operations

- Disposal including retrieval, pretreatment, privatization, and the Hanford Tanks Initiative (HTI)

- Characterization for historical data evaluation

- Regulatory requirements.

Each TWRS engineering, operations, and safety program has the responsibility to evaluate its information requirements for safely operating and monitoring facilities that store, receive, retrieve, treat, or dispose of waste materials. These information requirements are associated with specific issues. The information required by each issue is assembled and documented through the DQO process (EPA 1994). The DQO process documentation defines information use, data quality, boundary requirements, and special handling requirements pertinent to sampling and analyses.

The DQO process is an iterative process which requires that a DQO be revised when the requirements and/or program needs for information change. The DQOs that deal with static, and safe storage issues (for example, flammable gas, organics, and safety screening) are being revised to show requirement changes and to include stakeholders (including Ecology and DOE-RL) in the DQO process. The DQOs that deal with dynamic issues (for example, waste compatibility and process treatment) are also being revised. A low-activity waste privatization DQO was released on December 12, 1996. Changes in waste sampling and analyses required by revisions to the DQOs will be reflected in revisions to the Waste Information Requirements Document and to the tank sampling and analysis plans that are prepared for most sampling and analysis activities. 
Supplemental requirements documents arise from analysis or evaluation of information on a subject or issue. These documents specify additional information requirements needed to address or resolve a specific issue.

The DQOs and supplemental requirement documents are listed in Section 8.0.

\subsection{INFORMATION REQUIREMENTS AND ISSUES}

Waste information requirements address the resolution of technically-based issues including: 1) safety issue resolution, 2) ongoing process operations, 3) disposal, 4) evaluation of historical data, and 5) regulatory issues. Each category has several specific issues and/or have special data requirements that distinguishes it from other categories. Each issue is associated with a DQO that describes data requirements and decisions to be made. A summary of issues associated data requirements and DQOs is provided below. These issues are discussed in detail in the Tank Characterization Technical Sampling Basis (Brown et al. 1997).

\subsubsection{Safety Issue Resolution}

The safety issue resolution program addresses flammable gas, organic fuels, high heat/tank 241-C-106 retrieval, safety screening, vapor screening, organic solvents, and vapor space phenomenology.

5.1.1.1 Flammable Gas. The possibility of releasing flammable gases into the headspace of a waste tank is a major issue because the ignition of confined gases could result in a release of radioactive and chemical materials to the environment. The issue of flammable gas release has been addressed by the Flammable Gas Tank Safety Program in Flammable Gas Tank Safety Program: Data Requirements for Core Sample Analysis Developed Through the Data Quality Objectives Process (McDuffie 1995). Flammable gas requirements for single-shell tank (SST) core samples are discussed in the Application of "Flammable Gas Tank Safety Program: Data Requirements for Core Sample Analysis Developed Through the Data Quality Objective Process," Rev. 2 (Cash 1996a).

Currently, three approaches are used to obtain information for addressing the flammable gas issue:

1. Measure gases released into the headspace.

2. Determine gas retention in the liquid and solid waste.

3. Determine chemical and physical properties of the waste that could affect gas generation, retention, and release. 
5.1.1.2 Organic Fuels. In sufficiently high concentrations with nitrates and/or nitrites and at sufficiently high temperatures, organic complexants can support a propagating chemical reaction. Organic complexant and solvent degradation products have been widely distributed in the tanks from waste management activities (Agnew 1996). Information requirements to address this issue are described in Data Quality Objective to Support Resolution of the Organic Complexant Safety Issue (Turner et al. 1995). Changes in applicability and use are described in Implementation Change Concerning Organic DQO, Rev. 2 (Meacham 1996a), and Increase Scope to Organic DQO (Meacham 1996b).

The organic DQO focuses on tanks that contain or may contain (based on safety screening and process history) organic compounds in concentrations above established decision thresholds. The organic DQO identifies the information needed to assess whether tanks should be retained or added to the Organic Watch List. A program logic change has been implemented by Implementation Change Concerning Organic DQO, Rev. 2 (Meacham 1996a). This change requires total organic carbon (TOC) analysis as a secondary analyte for all samples that exhibit any exotherm when analyzed by differential scanning calorimetry. If the TOC value is above the threshold prescribed in the organic DQO, additional analyses will be conducted according to the organic DQO.

The following organics issue concerns are being evaluated:

1. Identifying tanks that contain sufficiently high concentrations of fuel-rich organics to pose a risk for propagating reaction

2. Determining whether organic complexants rapidly degrade to oxalate, formate, and carbonate, thereby posing no risk (Camaioni et al. 1996)

3. Determining whether organic complexants remain soluble in saturated salt media (Barney 1996) and, if so, determining whether they can be removed by salt well pumping

4. Determining whether wastes are resistant to drying out at tank ambient operating conditions.

5.1.1.3 High Heat/Tank 24I-C-106 Retrieval. Tank 241-C-106 has been used for radioactive waste storage since mid-1947. Based on its capacity to store waste, this tank unintentionally received an excess of sludge containing high levels of strontium- 90 . The current heat load of tank $241-\mathrm{C}-106$ is estimated at approximately $110,000 \mathrm{Btu} / \mathrm{hr}$, which exceeds the heat load limit of $40,000 \mathrm{Btu} / \mathrm{hr}$ and classifies the tank as a high-heat load tank. Tank 241-C-106 is the only single-shell tank on the Hanford Site where the high heat generated by the stored waste is a concern.

To eliminate high-heat problems, tank $241-\mathrm{C}-106$ is designated for sluicing, retrieval, and waste transfer to tank 241-AY-102. During and after the sluicing of tank 241-C-106, grab 
samples from both tanks will be needed to verify process control and to demonstrate the success of the project. A process control plan will be written to identify when samples are needed during the sluicing process and what analyses should be performed. Sluicing is scheduled to start in September 1998.

\subsubsection{Safety Screening. In response to the recommendations of the DNFSB} (DOE-RL 1996), all tanks will be screened for safety issues with respect to uncontrolled exothermic chemical reactions, the presence of flammable gases in the headspace of the tank, and the potential for nuclear criticality. Each safety issue has an associated threshold, which if exceeded, would lead to further analysis to determination of safety conditions. Information requirements of the safety screening issue are described in Tank Safety Screening Data Quality Objective (Dukelow et al. 1995). This DQO applies to all tanks. Currently, all tanks are scheduled to be sampled for safety screening. If a technically justified argument can be provided not to safety screen all tanks, then the requirement to sample all tanks may be removed.

Safety screening analysis has shown high exotherms and TOC concentrations in some tanks not previously suspected of containing organic material. These findings have led to a change in the safety screening decision logic. This change is specified in Implementation of Change Concerning Organic DQO, Rev. 2 (Meacham 1996a). The current safety screening DQO (Dukelow et al. 1995) requires TOC analysis for samples that exceeded the differential scanning calorimetry threshold of $480 \mathrm{~J} / \mathrm{g}$. The change in the safety screening decision logic requires TOC analysis for all tanks exhibiting any exotherm.

5.1.1.5 Vapor Screening/Organic Solvents. Characterizing vapors in waste tank headspace is necessary to identify potentially hazardous waste storage conditions, to support the worker health and safety assurance strategy, and to ensure regulatory compliance.

Information requirements for all passively ventilated tanks are described by the Data Quality Objectives for Tank Hazardous Vapor Safery Screening (Osborne and Buckley 1995).

Information requirements for all tanks to be rotary-mode sampled are described by the Rotary Core Vapor Sampling Data Quality Objective (Price 1994) and the Data Quality Objective for Regulatory Requirements for Hazardous and Radioactive Air Emissions Sampling and Analysis (Mulkey and Markillie 1995) as amended by Status of the Current Understanding of the Toxic Air Pollutants (TAPS) and Hanford Tank Farm Vapor Space Characterization; Recommended Path Forward and Justificarion for Continued RMCS Exhauster Operations (Laws 1996).

All 177 underground tanks must be vapor-sampled for organic solvent screening according to the Recommendation 93-5 Implementation Plan (DOE-RL 1996). Additional requirements for organic solvent screening are documented in the Scope Increase of "Duta Quality Objective to Support Resolution of the Organic Complexant Safery Issue" (Cash 1996b). Until the organic solvent screening DQO can be completed, the hazardous vapor screening DQO will be used to obtain the necessary information for the organic solvent issue. 
5.1.1.6 Vapor Space Phenomenology. An understanding of headspace vapor phenomenology is essential to ensure that vapor samples are meaningful and that results can be used with confidence to resolve vapor issues. The requirements for characterization of vapor samples to support the vapor space phenomenology issue are outlined in the Recommendation 93-5 Implementation Plan (DOE-RL 1996), with the exception of the third issue listed below which is driven by the Tri-Party Agreement requirement to close the flammable gas USQ.

The following three headspace concerns have been identified as critical to the technical basis of the vapor sampling effort.

1. Whether samples, collected from a single tank headspace location, generally represent headspace (homogeneity). If large differences in composition exist from one location to another, samples at multiple locations would be required for vapor space characterization.

2. The changes in headspace vapor composition over time.

3. The affect of the exchange of atmospheric air and tank headspace vapor, or exchanges between overflow (cascade) connected tanks on the homogeneity and composition of tank headspace vapor. Specific data requirements to obtain this information have been developed in the Vapor Sampling and Analysis Plan/Test Plan for Temporal Srudies of Tanks BX-104, BY-108, C-107 and S-102 (Buckley 1997) and the Vapor Sampling and Analysis Plan for Headspace Homogeneiry Tests of Tanks B-103, TY-103, and U-112 (Buckley 1996).

\subsubsection{Operations and Maintenance}

TWRS operations and maintenance organization is responsible for all waste transfers in the 200 Area tank farms. The waste transfers are associated with the stabilization program (waste transfers), evaporator operations, and caustic mitigation storage issues. The concerns of these programs include worker safety, environmental regulations, and operation efficiency. The programs and associated applicable DQOs are described below.

5.1.2.1 Waste Transfers. Information requirements to support waste compatibility issues and waste transfers are described by the Datu Qualiry Objectives for Tank Farms Waste Compatibility Program (Fowler 1995). Waste transfers that require compatibility information include transfers from double-shell tank (DST) to DST, SST to DST, and processes that generate waste for tank storage.

All DSTs are within the scope of the compatibility DQO. The SSTs are within the scope of the compatibility DQO only if waste is scheduled to be transferred out of an SST for tank stabilization. 
There are two functions associated with sampling and analyzing for compatibility. The first function is to ensure that DSTs comply with existing requirements and guidelines including operating specification document limits, operational safety requirements, and criticality prevention specifications. The guidelines are based on chemical or physical measurements of the waste. The second function is to ensure that the potential for release of HLW is not increased with a transfer into a DST.

5.1.2.2 Evaporator Operations. Successful operation of the 242-A Evaporator requires information about evaporator feed waste. Information requirements are described in 242-A Evaporator/Liquid Effluent Retention Facility Data Quality Objectives (Von Bargen 1995).

Tank 241-AW-102 is the evaporator feed tank. Tank 241-AW-106 receives the evaporator bottoms after waste evaporation and is called the slurry tank. Evaporator condensate is sent to the Liquid Effluent Retention Facility. Tanks that transfer waste to the feed tank for processing in the evaporator are called candidate feed tanks. Candidate feed tanks currently include 241-AP-103, 241-AP-104, 241-AP-105, 241-AP-106, 241-AP-107, 241-AP-108, 241-AN-101 and 241-AY-101. Candidate feed tanks are the only tanks for which information is required to support evaporator operations.

Sampling and analyzing evaporator feed tanks provides data that supports the following three evaluations by the evaporator program.

1. Process control evaluation ensures the evaporator operates efficiently with minimal equipment depreciation. This evaluation also compares the waste compatibility in the candidate feed tanks with the wastes in the feed and slurry tanks.

2. Safety evaluation ensures that hazardous wastes do not endanger workers or the environment.

3. Environmental compliance evaluation ensures that the waste released to the slurry tank, the gases released to the air, and the water released to Liquid Effluent Retention Facility are in compliance with environmental limits.

5.1.2.3 Caustic Mitigation. Some DSTs have predicted corrosion rates affected by chemical concentrations that are not within the operating specifications determined by the aging waste operating specification document (LMHC 1996). These tanks are called "caustic deficient." Operations often require information on the caustic level of these tanks. Currently, no DQO exists which describes the information requirements of caustic deficient tanks. When information is required, operations provide a request for sampling analysis or a process memorandum to direct characterization work. 
Only DSTs are required to remain within the operating specifications outlined in the aging waste operating specification document (LMHC 1996). The DSTs which are currently labeled caustic deficient include tanks 241-AN-107, 241-AN-102, 241-AP-103, and 241-AY-101.

Waste information is needed to determine the predicted corrosion rate of a tank. Characterization information obtained for caustic deficient tanks is evaluated to determine whether caustic additions to the tank will bring it back within specification or whether another type of mitigation effort is necessary.

The sampling and analysis of caustic deficient tanks is schedule-driven. When a DST falls out of operating limits, operations will determine whether characterization sampling and analysis is required.

\subsubsection{Disposal}

The disposal program is responsible for retrieval, pretreatment, privatization, and HTI projects. The information requirements and associated DQO requirements for the information are described below.

5.1.3.1 Retrieval. In the Hanford Federal Facility Agreement and Consent Order (Ecology et al. 1996), the Department of Energy agreed to retrieve all tank wastes for pretreatment and disposal. Single-shell tank wastes will be mobilized by sluicing, then transferred to a holding tank by a slurry pump. Double-shell tank sludge will be mobilized by mixer pumps, then transferred by slurry pump.

Information requirements to support retrieval are described by Characterization Data Needs for Development, Design, and Operation of Retrieval Equipment Developed Through the Data Quality Objective Process (Bloom and Nguyen 1996). Most data requirements are being met by evaluating historical data and sampling conducted for other programs. However, future needs include in-situ measurements and ex-situ analysis of tank samples in support of specific retrieval activities. The retrieval DQO focuses on the physical property measurement needed to design appropriate waste retrieval equipment.

Usually, the retrieval DQO requires sample material for process testing but does not require Characterization Project analysis. Specific tanks to meet retrieval requirements are defined in the technical sampling basis (Brown et al. 1997).

5.1.3.2 Pretreatment. Pretreatment information requirements are discussed in Data Needs and Attendant Data Quality Objectives for Tank Waste Pretreatment and Disposal (Slankas et al. 1995), Strategy for Sampling Hanford Site Tank Wastes for Development of Disposal Technology (Kupfer et al. 1995), the Phase One High-Level Waste Pretreatment and Feed Staging Plan (Manuel 1996), and the Tank Characterization Technical Sampling Basis (Brown et al. 1997). 
Solid tank wastes will be pretreated to separate them into HLW and LAW streams. The HLW stream contains the bulk of the radionuclides. The LAW stream contains the bulk of the chemical waste in tanks, a much larger volume. Information requirements fall into the following two categories.

1. Information on tank solids to evaluate chemical and physical behavior of sludge washing and settle decant testing.

2. Information on tank supernatant to evaluate liquid pretreatment technologies (especially cesium removal). Characterization to evaluate sludge washing and settle decant behavior is also needed. Information requirements to evaluate liquid pretreatment technologies is included in Section 5.1.3.3 under the privatization issue.

To date, a number of tank samples have been evaluated for sludge washing characteristics (Lumetta and Rapko 1994, Lumetta et al. 1994, Lumetta et al. 1996, Rapko et al. 1995, Temer and Villarreal 1995a, 1995b, and 1996). Additional tank samples will be required for sludge washing, as addressed in Kupfer et al. (1995).

The pretreatment strategy has recommended sampling 47 SSTs and 12 DSTs to support key TWRS decisions associated with pretreatment and vitrification. The strategy outlines the process testing to be done on waste samples. Although Characterization Project analyses are not required, archive sample material may be requested from the Project for process testing. Sample material from other tanks may be supplied to the pretreatment/disposal programs to augment their information basis. Tanks with respective dates identified to meet pretreatment requirements are defined in Brown et al. (1997).

5.1.3.3 Privatization. The waste information requirements for the TWRS LAW privatization program are discussed in Data Requirements for TWRS Privatization Characterization of Potential Low Activity Waste. Feed (Jones and Wiemers 1996), and the Preliminary Low-Level Waste Feed Staging Plan (Certa et al. 1996). A DQO for waste characterization of HLW (sludge/saltcake) has not been developed yet. However, characterization requirements are identified in the Phase One High-Level Waste Pretreatment and Feed Staging Plan (Manuel 1996).

The treatment and disposal of tank waste are expected to be contracted to private companies under a Department of Energy initiative called "privatization." Gathering information on the composition of waste in specific tanks is a high priority so that potential contractors can develop and construct the proper process for waste treatment and the management and integrating contractor can select, stage, and provide waste to the private contractor. Additional DQOs are being developed to identify characterization data requirements to support resolution of feed staging issues. Specific tanks needed to meet privatization requirements are defined in Brown et al. (1997). 
5.1.3.4 Hanford Tanks Initiative. The HTI is a four-year project (1997-2000) resulting from the technical and financial partnership of the Department of Energy Office of Waste Management and the Office of Science and Technology. The purpose of the HTI is to accelerate activities to gain key technical, cost performance, and regulatory perspectives on two HLW tanks (tanks 24l-AX-104 and 241-C-106). The HTI will define the process, criteria, and technology to support retrieval performance objectives of single-shell tanks.

A DQO will be written specifically for the sampling of tank 241-AX-104 to address the information requirements. A statistical-based sampling strategy plan (Jensen and Reich 1997) has been written to provide the information required for the DQO. A light-duty utility arm may be used to take samples from in-tank equipment (such as the air lift circulator and thermocouple trees) and from the headspace. A strategy for analysis of tank 241-C-106 is being written. The DQO process will follow.

\subsubsection{Characterization for Historical Data Evaluation}

Throughout the life of the operating facilities at Hanford, process information has been generated including waste transfer logs, chemical purchase records, and process flow sheets. Efforts have been made to use that historical information for characterizing waste tank contents. This includes creating models for specific waste types within the tank, along with their spatial variability and contribution to total tank inventory (Agnew et al. 1997).

Information requirements for evaluating historical data are described in the Historical Model Evaluation Data Requirements (Simpson and McCain 1997). Bounding tanks and alternates. are listed as well as the key analyses required to evaluate waste types and inventory.

The Hanford Defined Waste model, developed by the Los Alamos National Laboratory, uses historical information from waste transfer logs, chemical purchase records, and process flow sheets to estimate the contents of waste tanks (Agnew 1997). Currently, the Hanford Defined Waste model is not used for decision-making because the data quality and the assumptions driving the model have not been fully evaluated.

The purpose of the historical model evaluation DQO (Simpson and McCain 1997) is to evaluate the ability of the Hanford Defined Waste model to accurately predict tank waste composition.

Simpson and McCain (1997) have identified seven bounding tanks and 11 alternative tanks to meet historical model evaluation needs. They identify the acquisition and analyses of samples from each tank to determine the range of compositions encountered in each major waste type that has contributed to the overall tank contents. 


\subsubsection{Regulatory Compliance Issues}

Regulatory compliance is responsible for meeting the regulatory laws which apply to waste tanks. Information requirements are directed towards air emissions and dangerous waste. These issues are described below.

5.1.5.1 Regulatory Issues for Air Emissions. Characterization sampling and analysis of tank headspace is to be conducted according to the Data. Quality Objectives for Regulatory Requirements for Hazardous and Radioactive Air Emissions Sampling and Analysis (Mulkey and Markillie 1995). This DQO applies to all DSTs and SSTs whether actively or passively ventilated.

Sampling the surface layer of each tank for total organic concentration is required to establish whether a floating organic layer is present, and if so, its effect on air emissions. If a surface layer sample has been collected, and the tank has had no transfers since the previous collection, additional sampling is not required.

5.1.5.2 Regulatory Issues for Dangerous Waste. Regulatory information on solid and liquid components of tank waste material is required according to the Data Quality Objectives for Regulatory Requirements for Dangerous Waste Sampling and Analysis (Mulkey 1996). This information is to be collected opportunistically along with sampling for other programs and projects.

\subsection{ISSUE PRIORITIZATION AND TECHNICAL SAMPLING BASIS}

Brown et al. (1997) discuss technical issues for resolution, prioritizes tanks for sampling, and provides a technical basis for developing an operationally-based sampling schedule. Information gained from the sampling and analysis effort is subsequently used to update program issues. These updates will be reflected in the annual Waste Information and Requirements Document. Brown et al. (1997) reflect the issues that are described in Section 4.1 of this document and that are listed in descending order of priority below. The priorities were developed by and in consensus with TWRS programs, DOE-RL, and Ecology:

- Flammable gas

- Organic fuels

- Compatibility

- High-heat/tank 241-C-106

- Evaporator

- Vapor space phenomenology

- Vapor screening/organic solvents

- $\quad$ Safety screening

- Caustic mitigation

- Privatization 
- Retrieval

- Pretreatment

- Historical model evaluation

- Hanford Tanks Initiative.

The Waste Information Requirements Document concept was developed after the release of the technical sampling basis (Brown et al. 1997). In the future, the Waste Information and Requirements Document will provide input to the technical sampling basis which, in turn, will prioritize document requirements and be followed by the final Waste Information and Requirements Document after application of constraints discussed in Section 5.3.

\subsection{ASSUMPTIONS AND BASIS FOR WORK ESTIMATES}

Most Characterization Project contributions to TWRS information requirements are through the collection and analysis of waste tank samples. Once program information requirements are prioritized (Brown et al. 1997), these requirements are integrated with operational constraints to form the basis of the Characterization Project work scope. Operational constraints will often change the order in which samples are taken and analyzed. These constraints take the form of additional program directions and/or sampling equipment capabilities and availability.

After tanks have been selected for sampling, a tank sampling and analysis plan is prepared to describe how the sampling and analyses are to be done. Removing samples from the tank begins the operation phase of the characterization process and establishes the baseline for characterization deliverable schedules. Once samples are removed, they are delivered to the laboratory for analysis. The data from the analysis is used to address all applicable issues. The time requirement for deliverables is described below.

\subsubsection{Operational Constraints}

Characterization project deliverables for a fiscal year are subject to operation constraints. The major constraints contributing to changes in the sampling order of tanks and the number of samples taken each fiscal year are described below.

5.3.1.1 Program Direction. Occasionally, the TWRS program office responsible for a DQO may request that tanks high on the priority list not be sampled in the near term. This usually occurs when more information is needed before a tank is sampled or when the number of tanks requiring sampling is modified. 
5.3.1.2 Sampling Equipment Capabilities and Availability. Current condensed phase tank sampling methods include grab, auger, and core sampling. Grab sampling is used on tanks expected to be homogenous and mostly liquid. Auger sampling is used on tanks with less than 15 inches of waste and no drainable liquid. Core sampling is required on all other tanks to obtain a full depth profile of the tank waste. There are currently four core sampling trucks. Two core sampling trucks are restricted to sampling in push mode (trucks 1 and 2), and two trucks sample in push or rotary mode (trucks 3 and 4). Push mode is for soft waste that the sampler can be pushed through to collect the sample. Rotary mode sampling is used where the waste is too hard to be push mode sampled. Push mode retained gas sampling (RGS), a variation of push mode sampling, captures gases held in solid or liquid waste. Retained gas sampling can be accomplished only with truck 1 .

Rotary mode core sampling has recently become an authorized activity in flammable gas tanks. The Compensatory Actions for Open Discovery Unreviewed Safety Questions (Standing Order 97-01) (East and West Tank Farms 1997) is the authorization basis for work performed in the tank farms. This order categorizes tanks into one of three facility groups depending on the potential size of a gas release event. An additional group covers all other tanks.

Rotary mode core sampling has not occurred because of existing exhauster equipment limitations. Rotary mode sampling is being evaluated for use in SX tank farm which is actively ventilated. Until the evaluation has been completed and approved, core sampling systems are restricted to push mode sampling only. Approval to employ rotary mode core sampling is expected in late July 1997.

Two types of sampling devices are generally used to sample waste tank gases and vapors. SUMMA ${ }^{1}$ canisters are used to collect certain gases and volatile organic vapors, and sorbent traps are used to collect organic vapors and certain inorganic gases and vapors.

SUMMA ${ }^{\mathrm{TM}}$ canisters enable the collection and transfer of whole-air samples from location to an analytical laboratory where the sample can be analyzed. Despite being whole-air sampling devices, SUMMA ${ }^{\mathrm{TM}}$ canisters are not appropriate sampling devices for highly polar or water soluble vapors such as ammonia and acid gases (for example, nitric oxide, nitrogen dioxide, sulfur dioxide).

Sorbent traps are used to sample organic vapors and specific inorganic gases and vapors in waste tank headspace. Unlike SUMMA ${ }^{\text {TM }}$ canisters, sorbent traps concentrate targeted analytes by selectively removing them from the air sample and other constituents of the air (for example, oxygen, nitrogen, argon, etc.) are not collected.

\footnotetext{
'SUMMA is a trademark of Molectrics, Inc.. Cleveland, Ohio.
} 
After sampling is complete, sorbent traps are sealed and sent to a laboratory for analysis. At the analytical laboratory, the analyte is extracted from the sorbent media and measured. Given the quantity of analyte recovered and the total volume of air sampled, the concentration of the analyte in the original air sample is calculated.

Two types of sampling equipment are used to collect gas and vapor samples from waste tanks. Each has advantages and disadvantages. The vapor sampling system (VSS) is designed for the collection of large numbers of samples from tanks with high headspace temperatures and high vapor concentrations. The in situ vapor sampling (ISVS) system offers, by comparison, a relatively simple method for sampling waste tank headspace with a minimum of tank preparation and field work.

The VSS consists of a mobile laboratory, a hot-water jacketed stainless steel probe that is inserted into the tank headspace, and stainiess steel transfer tubing that connects the mobile laboratory with the probe. Sample air is drawn from the tank headspace and through the transfer tubing and sampling manifold by an air pump. Mahon et al. (1994) describe the VSS, its performance, and its operation in detail.

The ISVS method uses an alternative approach to sample collection. Rather than transferring the air, gases, and vapors to be sampled to a remote location, the sampling devices themselves (specifically sorbent traps) are lowered down into the tank headspace.

\subsubsection{Deliverable Time Requirements}

Time requirements are divided into the three primary activities of the sampling and analysis process: sample acquisition, sample analysis, and production of a report.

5.3.2.1 Sample Acquisition Time Requirements. The time it takes to sample a tank is determined by the equipment set up time, the waste depth, and the equipment maintenance/repair time. Grab sampling and auger sampling take the least amount of time. Core sampling times vary depending on the number of segments in a core and the waste that is being sampled. In core sampling, many operational issues vary the time required to take a sample. All known parameters are taken into consideration when the sampling schedule is created.

5.3.2.2 Sample Analysis Time Requirements. The tank sampling and analysis plan specifies the analyses and the parameters for analyses on each tank sample. The number of samples, the number of analyses, the complexity of the analyses and the current workload in the laboratory factor into the time required for analyses. The pretreatment and retrieval DQOs only need sample material and not sample analysis. The hazardous vapor DQO contains a long list of volatile and semivolatile constituents that require analysis. Details are provided in the DQO. 
Data are expected to be available from each tank sampling event at different intervals depending on the type of sample, the analyses required, and the type of report. Average tumaround times for non-RGS tank sample analysis, RGS tank sample analysis, and combustible gas measurements have been established. For current turnaround time commitments, refer to the Fiscal Year 1997 Memorandum of Understanding for the TWRS Characterization Project (Schreiber 1997).

5.3.2.3 Report Production Time Requirements. After the laboratory completes the analyses on tank samples and produces a final report, the data are evaluated to determine whether the appropriate issues have been addressed. This evaluation can take many forms depending on the issues involved and the format of the milestone or deliverable that was driving the issue. Usually, the current tank status and the results of the sampling event are documented in a TCR. The time required to evaluate the data or write a TCR varies with the complexity of the tank history, applicable DQOs, and the amount of data available from the analyses. Current turnaround time commitments for TCR production are contained in Fiscal Year 1997 Memorandum of Understanding for the TWRS Characterization Project (Schreiber 1997). 


\subsection{INFORMATION REQUUREMENTS MATRIX}

\subsection{INFORMATION REQUIREMENTS MATRIX CONTENT}

The information requirements matrix content (see Table 6-1) identifies or provides information on Characterization Project deliverables related to their TWRS project drivers. The matrix also identifies the number of deliverables that can be completed in a fiscal year. Future revisions of the Waste Information Requirements Document will include information to FY 2002 or beyond. The matrix consists of eight columns as described below.

The TWRS milestone and driver information includes the following:

- Column 1 lists program issues being addressed by TWRS.

- Column 2 lists the milestone numbers that require Characterization Project support. The milestone numbers are associated with the program issues in column 1 and Characterization Project deliverables in column 4.

- Column 3 gives the date that the TWRS milestone or driver is due to be submitted to DOE-RL.

The Characterization Project support information includes the following:

- Column 4 lists the deliverables that will be provided and signifies completion of the Characterization Project's responsibility in supporting the milestone in column 2.

- Columns 5 and 6 list the number of each deliverable type that will be delivered by the Characterization Project in FY 1997.

- Columns 7 and 8 list the number of each deliverable type that will be delivered by the Characterization Project in FY 1998.

Table 6-2 lists opportunistic analyses requested by some TWRS programs and is presented in the same format as Table 6-1. Opportunistic analyses are laboratory analyses that are performed on sample material acquired for a different program. That is, some programs do not specifically drive the sampling of a tank, but request "opportunistic" analytical information from the samples taken for other programs. Opportunistic analysis, like any other sample analysis, is requested and justified in a DQO report. Management decision is required to determine if the opportunistic analyses will be performed for the requesting program. 
When using Tables 6-1 and 6-2, it is important to understand that there is a time lag between the tank sampling event and the completion of the laboratory analysis (as reported in the laboratory analysis report). The time lag between sampling and the analysis report is often dependant upon the amount of analysis or difficulty of the analysis required. There is another time lag between completion of the laboratory analysis report and completion of the TCR. The acceptable time lag between sampling, analysis, and TCR evaluation of the data is reported in the memorandum of understanding (Schreiber 1997) and may be updated as necessary.

Time lag between sampling, analysis, and TCR is evident in Tables 6-1 and 6-2 in the rows reporting sampling, analysis report, and TCR support of a milestone. If, for example, a sample was taken in FY 1996 but not analyzed until FY 1997, the sampling event would not be recorded in Tables 6-1 and 6-2 but the laboratory report and subsequent TCR would be recorded. Likewise, a tank sampled and analyzed in FY 1998 would be reflected in Tables 6-1 and 6-2 but the TCR would not be reflected in the table if it was not written until FY 1999. 
Table 6-1. Information Requirements Matrix. (10 sheets)

\begin{tabular}{|c|c|c|c|c|c|c|c|}
\hline \multirow{3}{*}{ program or losic } & \multirow{2}{*}{\multicolumn{2}{|c|}{ MWR Driver: }} & \multicolumn{5}{|c|}{ 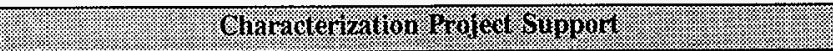 } \\
\hline & & & \multirow[b]{2}{*}{ Beliverable'? } & \multicolumn{2}{|c|}{ 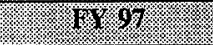 } & \multicolumn{2}{|c|}{17198} \\
\hline & $\begin{array}{l}\text { Milestone or } \\
\text { Briver }\end{array}$ & $\begin{array}{l}\text { Milestone } \\
\text { Due Date }\end{array}$ & & Samples & Tanks. & Samos! & Trank \\
\hline \multirow[t]{7}{*}{ Flammable Gas } & \multirow{4}{*}{$\begin{array}{c}\mathrm{M}-40-00 \\
\mathrm{M}-40-09\end{array}$} & \multirow{4}{*}{$\begin{array}{l}9 / 30 / 2001 \\
9 / 30 / 1998\end{array}$} & Push Mode (RGS) Sampling & 10 & 4 & 5 & 3 \\
\hline & & & Push (RGS) Laboratory Report & - & 7 & - & 4 \\
\hline & & & $\begin{array}{l}\text { New Tank Characterization } \\
\text { Report }\end{array}$ & - & 4 & - & 4 \\
\hline & & & Flammable Gas DQO Revision & - & 1 & - & - \\
\hline & \multirow[t]{3}{*}{$5.6 .3 .1 . \mathrm{G}$} & \multirow[t]{3}{*}{$3 / 31 / 1998$} & Push Mode (RGS) Sampling & 3 & 1 & 3 & 2 \\
\hline & & & Push (RGS) Laboratory Report & - & 5 & - & 1 \\
\hline & & & $\begin{array}{l}\text { New Tank Characterization } \\
\text { Report }\end{array}$ & - & 4 & - & 1 \\
\hline \multirow[t]{5}{*}{ Organic Fuels } & \multirow{5}{*}{\begin{tabular}{|c}
$\mathrm{M}-40-00$ \\
$\mathrm{M}-40-09$ \\
$5.4 .3 .3 \mathrm{~B}$
\end{tabular}} & \multirow{5}{*}{$\begin{array}{l}9 / 30 / 2001 \\
9 / 30 / 1998 \\
11 / 30 / 1998\end{array}$} & Push Mode Sampling & 9 & 5 & 4 & 2 \\
\hline & & & Rotary Mode Sampling & - & - & 20 & 10 \\
\hline & & & Laboratory Analysis Report & - & 10 & - & 10 \\
\hline & & & $\begin{array}{l}\text { New Tank Characterization } \\
\text { Report }\end{array}$ & - & 8 & - & 8 \\
\hline & & & $\begin{array}{l}\text { Revised Tank Characterization } \\
\text { Report }\end{array}$ & - & - & - & 1 \\
\hline
\end{tabular}


Table 6-1. Information Requirements Matrix. (10 sheets)

\begin{tabular}{|c|c|c|c|c|c|c|c|}
\hline 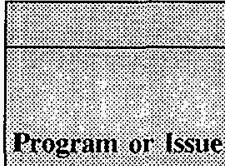 & $\begin{array}{l}\text { TURS Drifer } \\
\text { Milestonie or } \\
\text { Driver? }\end{array}$ & $\begin{array}{l}\text { Wilestone } \\
\text { Due Date }\end{array}$ & 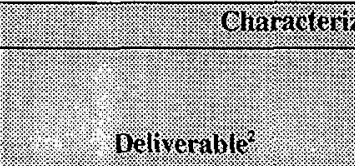 & 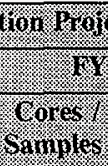 & 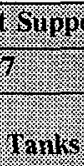 & $\frac{1}{\text { Cores }}$ & Thinks: \\
\hline \multirow{4}{*}{$\begin{array}{l}\text { Organic Fuels } \\
\text { (Cont'd) }\end{array}$} & \multirow[t]{4}{*}{ 5.6.3.1G } & \multirow[t]{4}{*}{$3 / 31 / 1998$} & Push Mode Sampling & 3 & 1 & 2 & 1 \\
\hline & & & Rotary Mode Sampling & - & - & 16 & 8 \\
\hline & & & Laboratory Analysis Report & - & 1 & - & 6 \\
\hline & & & $\begin{array}{l}\text { New Tank Characterization } \\
\text { Report }\end{array}$ & - & 3 & - & 4 \\
\hline \multirow[t]{7}{*}{ Compatibility } & \multirow[t]{5}{*}{$\begin{array}{r}\mathrm{M}-41-00 \\
\mathrm{M}-41-21 \\
\mathrm{M}-41-22 \\
\mathrm{M}-41-23 \\
\mathrm{M}-41-24\end{array}$} & \multirow[t]{5}{*}{$\begin{array}{l}9 / 30 / 2000 \\
5 / 31 / 1997 \\
9 / 30 / 1997 \\
3 / 31 / 1998 \\
9 / 30 / 1998\end{array}$} & Grab Sampling & 4 & 4 & - & - \\
\hline & & & Push Mode Sampling & 5 & 2 & 2 & 1 \\
\hline & & & Rotary Mode Sampling & - & - & 2 & 1 \\
\hline & & & Laboratory Analysis Report & - & 8 & - & 1 \\
\hline & & & Compatibility DQO Revision & 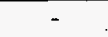 & 1 & - & - \\
\hline & \multirow{2}{*}{$\begin{array}{l}\text { Authorization } \\
\text { Basis }\end{array}$} & \multirow[t]{2}{*}{ N/A } & Grab Sampling & 3 & 3 & 4 & 4 \\
\hline & & & Compatibility DQO Revision & - & 1 & - & - \\
\hline
\end{tabular}


Table 6-1. Information Requirements Matrix. (10 sheets)

\begin{tabular}{|c|c|c|c|c|c|c|c|}
\hline \multicolumn{3}{|c|}{ 1.9. WRS Briver } & \multicolumn{5}{|c|}{ 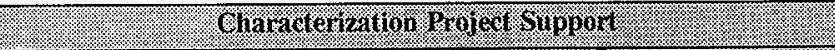 } \\
\hline 1.: & & & & Wy & & (2) & 8 \\
\hline Progran on 1 issue & $\begin{array}{l}\text { Wilestone or } \\
\text { brivert }\end{array}$ & $\begin{array}{l}\text { Milestonie } \\
\text { Bue Bate. }\end{array}$ & Belverable: & Youngs & ranis: & Sampick & 3ank \\
\hline $\begin{array}{l}\text { High-Heat/tank } \\
241-C-106\end{array}$ & $\begin{array}{l}\mathrm{M}-40-00 \\
\mathrm{M}-40-09\end{array}$ & $\begin{array}{l}9 / 30 / 2001 \\
9 / 30 / 1998\end{array}$ & Grab Sampling & - & - & 2 & 2 \\
\hline \multirow[t]{2}{*}{ Evaporator } & \multirow{2}{*}{$\begin{array}{l}\text { TWR-4.1.1 } \\
\text { FY } 97^{3} \\
\text { performance } \\
\text { agreement }\end{array}$} & \multirow[t]{2}{*}{$9 / 30 / 1997$} & Grab Sampling & 2 & 2 & 3 & 3 \\
\hline & & & Compatibility DQO Revision & - & 1 & - & - \\
\hline \multirow{6}{*}{$\begin{array}{l}\text { Vapor Space } \\
\text { Phenomenology }\end{array}$} & \multirow[t]{4}{*}{$5.6 .3 .1 . \mathrm{E}$} & \multirow[t]{4}{*}{$10 / 31 / 1997$} & Vapor Space Sampling & 28 & 7 & - & - \\
\hline & & & $\begin{array}{l}\text { Letter - Vapor Temporal } \\
\text { Studies }\end{array}$ & - & 1 & - & - \\
\hline & & & $\begin{array}{l}\text { Letter - Homogeneity (incl. } \\
\text { laboratory analysis) }\end{array}$ & $=$ & 1 & - & - \\
\hline & & & $\begin{array}{l}\text { Report - Temporal (incl. } \\
\text { laboratory analysis) }\end{array}$ & - & 14 & - & - \\
\hline & \multirow{2}{*}{$\begin{array}{r}M-40-00 \\
M-40-09\end{array}$} & \multirow{2}{*}{$\begin{array}{l}9 / 30 / 2001 \\
9 / 30 / 1998\end{array}$} & Vapor Space Sampling & 5 & 5 & 3 & 3 \\
\hline & & & Laboratory Analysis Report & - & - & - & 1 \\
\hline \multirow{3}{*}{$\begin{array}{l}\text { Vapor Screening/ } \\
\text { Organic Solvents }\end{array}$} & \multirow{3}{*}{$\begin{array}{r}5.4 .3 .4 \mathrm{D} \\
\mathrm{M}-40-00 \\
\mathrm{M}-40-09\end{array}$} & \multirow{3}{*}{$\begin{array}{l}12 / 31 / 1999 \\
9 / 30 / 2001 \\
9 / 30 / 1998\end{array}$} & Vapor Space Sampling & 14 & 14 & 11 & 11 \\
\hline & & & Vapor Laboratory Report & - & 18 & - & 16 \\
\hline & & & Organic Solvent DQO & - & 1 & - & - \\
\hline
\end{tabular}


Table 6-1. Information Requirements Matrix. (10 sheets)

\begin{tabular}{|c|c|c|c|c|c|c|c|}
\hline অ & WRS Driner & & Whanalew & 10\% 194 & (Supo & 器 & \\
\hline & & & l. & 18 & & 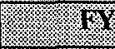 & 98 \\
\hline (1) & Milestone or & Milestone & & (com (1) & & Gorros/ & 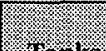 \\
\hline grogram or issue & & Bue vate. & Broprore & sampies & $1901 \%$ & & Fals \\
\hline $\begin{array}{l}\text { Vapor Screening } \\
\text { to support rotary } \\
\text { mode sampling }\end{array}$ & $\begin{array}{l}\text { Regulatory } \\
\text { Drivèrs }\end{array}$ & & Vapor Space Sampling & 13 & 13 & 11 & 11 \\
\hline \multirow{12}{*}{$\begin{array}{l}\text { Safety Screening/ } \\
\text { Safety - Waste }\end{array}$} & \multirow[t]{6}{*}{$5.6 .3 .1 . \mathrm{J}$} & \multirow[t]{6}{*}{$12 / 31 / 2002$} & Auger Sampling & - & - & 2 & 1 \\
\hline & & & Push Mode Sampling & 43 & 24 & 6 & 3 \\
\hline & & & Rotary Mode Sampling & - & - & 22 & 11 \\
\hline & & & Laboratory Analysis Report & - & 25 & - & 25 \\
\hline & & & $\begin{array}{l}\text { New Tank Characterization } \\
\text { Report }\end{array}$ & - & 16 & - & 16 \\
\hline & & & $\begin{array}{l}\text { Revised Tank Characterization } \\
\text { Report }\end{array}$ & - & - & - & 10 \\
\hline & \multirow[t]{6}{*}{$5.6 .3 .1 . \mathrm{G}$} & \multirow[t]{6}{*}{$3 / 31 / 1998$} & Push Mode Sampling & 3 & 1 & 2 & 1 \\
\hline & & & Rotary Mode Sampling & - & - & 18 & 9 \\
\hline & & & Laboratory Analysis Report & - & 8 & - & 6 \\
\hline & & & $\begin{array}{l}\text { New Tank Characterization } \\
\text { Report }\end{array}$ & - & 6 & - & 4 \\
\hline & & & $\begin{array}{l}\text { Letter - Sampling \& Analysis } \\
\text { of HPTs }\end{array}$ & - & - & - & 1 \\
\hline & & & Report - HPT Evaluation & - & - & - & 1 \\
\hline
\end{tabular}


Table 6-1. Information Requirements Matrix. (10 sheets)

\begin{tabular}{|c|c|c|c|c|c|c|c|}
\hline (3) & WRS Driver & ( & (3.). & 100 rojo & S Suppo & & \\
\hline (1) & 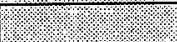 & & & TY & & Iy & 8 \\
\hline Program or lssie & $\begin{array}{l}\text { Milestone or } \\
\text { Driver }\end{array}$ & Wilestone & 44 Deliveraible & Saniples & 1.9114s: & 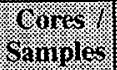 & \%anks: \\
\hline $\begin{array}{l}\text { Safety Screening/ } \\
\text { Safety - Waste }\end{array}$ & 5.6.3.1.C & $1 / 31 / 1997$ & $\begin{array}{l}\text { Letter - Format of Safety } \\
\text { Evaluation }\end{array}$ & - & 1 & - & - \\
\hline (Cont'd) & $5.6 .3 .1 . \mathrm{H}$ & $7 / 31 / 1998$ & Letter - Safety Evaluation & $=$ & - & - & 1 \\
\hline & & & $\begin{array}{l}\text { Report - Tank by Tank Safety } \\
\text { Evaluation }\end{array}$ & - & & - & - \\
\hline Caustic Mitigation & $\begin{array}{l}\text { Authorization } \\
\text { Basis }\end{array}$ & $\mathrm{NA}$ & Grab Sampling & 2 & 2 & 3 & 2 \\
\hline Privatization - & $M-60-00$ & $12 / 31 / 2024$ & Laboratory Analysis Report & - & 3 & - & - \\
\hline $\begin{array}{l}\text { Low Activity } \\
\text { Waste }\end{array}$ & $M-60-10$ & $\begin{array}{l}7 / 31 / 1998 \text { TBD } \\
12 / 31 / 2002\end{array}$ & $\begin{array}{l}\text { New Tank Characterization } \\
\text { Report }\end{array}$ & - & 3 & - & - \\
\hline & & & $\begin{array}{l}\text { Report - Update AN-105 Best } \\
\text { Basis Inventory }\end{array}$ & - & 1 & - & - \\
\hline & & & $\begin{array}{l}\text { Report - Evaluation of } \mathrm{AN}-104 \\
\text { for additional } \\
\text { sampling/analysis needs }\end{array}$ & - & 1 & - & - \\
\hline & & & $\begin{array}{l}\text { Report - Evaluation of } \mathrm{AN}-103 \\
\text { for additional } \\
\text { sampling/analysis needs }\end{array}$ & - & 1 & - & - \\
\hline
\end{tabular}


Table 6-1. Information Requirements Matrix. (10 sheets)

\begin{tabular}{|c|c|c|c|c|c|c|c|}
\hline Program or issue & $\begin{array}{l}\text { WRS Driver? } \\
\text { Milestone or } \\
\text { Driver? }\end{array}$ & $\begin{array}{l}\text { Whestone: } \\
\text { Due Date }\end{array}$ & 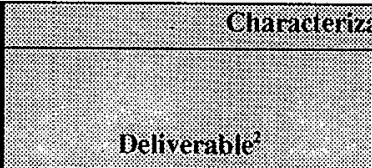 & 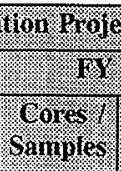 & 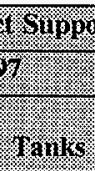 & 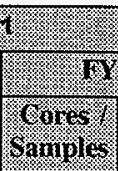 & $\frac{18}{4.5}$ \\
\hline \multirow[t]{8}{*}{$\begin{array}{l}\text { Privatization - } \\
\text { Low Activity } \\
\text { Waste } \\
\text { (Cont'd) }\end{array}$} & \multirow{8}{*}{$\begin{array}{r}\text { M-60-00 } \\
M-60-10 \\
M-60-11 \\
M-60-12 \\
\text { (Cont'd) }\end{array}$} & \multirow{8}{*}{$\begin{array}{l}\text { 12/31/2024 } \\
7 / 31 / 1998 \mathrm{TBD} \\
12 / 31 / 2002 \\
\text { (Cont'd) }\end{array}$} & $\begin{array}{l}\text { Report - Evaluation of AN-105 } \\
\text { for additional } \\
\text { sampling/analysis needs }\end{array}$ & - & 1 & - & - \\
\hline & & & $\begin{array}{l}\text { Report - Evaluation of } \mathrm{AW}- \\
101 \text { for additional } \\
\text { sampling/analysis needs }\end{array}$ & - & - & - & 1 \\
\hline & & & $\begin{array}{l}\text { Report - Evaluation of SY-101 } \\
\text { for additional } \\
\text { sampling/analysis needs }\end{array}$ & - & - & - & 1 \\
\hline & & & $\begin{array}{l}\text { Report - Evaluation of AN-102 } \\
\text { for additional } \\
\text { sampling/analysis needs }\end{array}$ & - & - & - & 1 \\
\hline & & & $\begin{array}{l}\text { Report - Evaluation of AN-107 } \\
\text { for additional } \\
\text { sampling/analysis needs }\end{array}$ & - & - & - & 1 \\
\hline & & & $\begin{array}{l}\text { Privatization LAW DQO } \\
\text { Revision }\end{array}$ & - & - & - & 1 \\
\hline & & & $\begin{array}{l}\text { Privatization LAW DQO } \\
\text { Revision (Phase I contracts) }\end{array}$ & $\overline{-}$ & - & - & 1 \\
\hline & & & $\begin{array}{l}\text { Privatization LAW DQO } \\
\text { Revision (Phase II contracts) }\end{array}$ & - & - & - & 1 \\
\hline
\end{tabular}


Table 6-1. Information Requirements Matrix. (10 sheets)

\begin{tabular}{|c|c|c|c|c|c|c|c|}
\hline (1. & WRSOrVer & & oraroterza & Hon Trow & S11010 & & \\
\hline ?.: & & & & (1. & & 1/ & 98 \\
\hline Prograni or issue & Mitustone or & Whilestorie & Deliverable? & Saringin & 然n & Samples & ranks. \\
\hline \multirow[t]{3}{*}{ Retrieval } & $\begin{array}{l}\mathrm{M}-45-00 \\
\mathrm{M}-45-\end{array}$ & $\begin{array}{l}9 / 30 / 2024 \\
10 / 31 / 1997\end{array}$ & Grab Sampling & - & - & 2 & 2 \\
\hline & $\begin{array}{l}03 \mathrm{~A} \\
5.4 .3 .6 . \mathrm{C}\end{array}$ & $10 / 31 / 1997$ & Grab Laboratory Report & - & - & - & 1 \\
\hline & TWR7.1.C & $4 / 25 / 1997$ & Grab Sampling & - & - & 2 & 1 \\
\hline \multirow[t]{3}{*}{ Pretreatment } & $\begin{array}{l}5.6 .3 .1 . \mathrm{G} \\
5.5 .6 .1 \mathrm{~A}\end{array}$ & $\begin{array}{l}3 / 31 / 1998 \\
3 / 31 / 1998\end{array}$ & Rotary Mode Sampling & - & - & 12 & 6 \\
\hline & $\begin{array}{l}\mathrm{M}-50-00 \\
\mathrm{M}-50-03-\end{array}$ & $\begin{array}{l}12 / 31 / 2028 \\
9 / 30 / 1997\end{array}$ & Push Mode Sampling & 12 & 6 & 2 & 1 \\
\hline & $\begin{array}{l}\text { T2C M-50- } \\
03\end{array}$ & $3 / 31 / 1998$ & Rotary Mode Sampling & - & - & 14 & 7 \\
\hline \multirow{7}{*}{$\begin{array}{l}\text { Historical Model } \\
\text { Evaluation }\end{array}$} & \multirow[t]{3}{*}{$5.6 .3 .1 . \mathrm{D}$} & \multirow[t]{3}{*}{$6 / 30 / 1997$} & Letter - HTCE & - & 1 & - & - \\
\hline & & & Report - HTCE & - & 3 & - & - \\
\hline & & & Report - Supporting Document & - & 12 & - & - \\
\hline & \multirow[t]{4}{*}{$5.6 .3 .1 . \mathrm{G}$} & \multirow[t]{4}{*}{$3 / 31 / 1998$} & Push Mode Sampling & - & - & 2 & 1 \\
\hline & & & Rotary Mode Sampling & - & - & 16 & 8 \\
\hline & & & Laboratory Analysis Report & - & 4 & - & 6 \\
\hline & & & $\begin{array}{l}\text { New Tank Characterization } \\
\text { Report }\end{array}$ & - & 3 & - & 3 \\
\hline
\end{tabular}


Table 6-1. Information Requirements Matrix. (10 sheets)

\begin{tabular}{|c|c|c|c|c|c|c|c|}
\hline \multicolumn{3}{|c|}{ IMRS Driver: } & \multicolumn{5}{|c|}{ Charraterizanion Proind Suppor, } \\
\hline & & 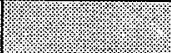 & & $1.7 \%$ & 97 & II & 98 \\
\hline Progranin or lissue & $\begin{array}{l}\text { Millestone or } \\
\text { Driver }\end{array}$ & $\begin{array}{l}\text { Milestone } \\
\text { Due bate }\end{array}$ & \%: 1.9 Deliverable'? & Sariniles: & (Ianiss & $\begin{array}{l}\text { (0ores. } \\
\text { Samiles }\end{array}$ & I. This: \\
\hline \multirow{4}{*}{$\begin{array}{l}\text { Historical Model } \\
\text { Evaluation } \\
\text { (Cont'd) }\end{array}$} & \multirow[t]{4}{*}{$5.6 .3 .1 . \mathrm{I}$} & \multirow[t]{4}{*}{$12 / 31 / 1998$} & Push Mode Sampling & 3 & 1 & 2 & 1 \\
\hline & & & Rotary Mode Sampling & - & - & 18 & 9 \\
\hline & & & Laboratory Analysis Report & - & 10 & - & 6 \\
\hline & & & $\begin{array}{l}\text { New Tank Characterization } \\
\text { Report }\end{array}$ & - & 9 & - & 4 \\
\hline \multirow{7}{*}{$\begin{array}{l}\text { Hanford Tanks } \\
\text { Initiative }\end{array}$} & \multirow{7}{*}{$\begin{array}{l}\mathrm{M}-45-00 \\
\mathrm{M}-45-06-\mathrm{T} 01\end{array}$} & \multirow[t]{7}{*}{$9 / 30 / 2024$} & Vapor Sampling & 1 & 1 & - & - \\
\hline & & & Auger Sampling & - & - & 2 & 1 \\
\hline & & & LDUA Sampling & - & - & 1 & 1 \\
\hline & & & Laboratory Analysis Report & - & 1 & - & 1 \\
\hline & & & $\begin{array}{l}\text { New Tank Characterization } \\
\text { Reports }\end{array}$ & - & - & - & $\mathrm{I}$ \\
\hline & & & AX-104 Sampling DQO & - & 1 & - & - \\
\hline & & & $\begin{array}{l}\text { Vadose Zone Sampling of AX- } \\
104 \text { DQO }\end{array}$ & - & - & - & 1 \\
\hline Air Emissions & \begin{tabular}{|l} 
Regulatory \\
Drivers
\end{tabular} & $9 / 30 / 1997$ & Air Emission DQO Revision & - & 1 & - & - \\
\hline
\end{tabular}


Table 6-1. Information Requirements Matrix. (10 sheets)

\begin{tabular}{|c|c|c|c|c|c|c|c|}
\hline & WhS Driver. & & Graracterin & Hon Prag & SUI & t. & \\
\hline l. & (1.: & & & (fil. & & 1) & 98. \\
\hline Program or issue & $\begin{array}{l}\text { Millestone or } \\
\text { ariver? }\end{array}$ & $\begin{array}{l}\text { Milestone } \\
\text { Bue Dite. }\end{array}$ & 4+? Deliverable? & Samples & Kanks & Sanesies & Tauks: \\
\hline Characterization & $5.6 .3 .1 . \mathrm{B}$ & $11 / 30 / 1996$ & Letter - Completion of FTIR & - & 1 & - & - \\
\hline Planning & $5.6 .3 .1 . \mathrm{F}$ & $11 / 30 / 1997$ & Letter - Inventory & - & 1 & - & - \\
\hline & $\begin{array}{r}\mathrm{M}-44-00 \mathrm{~A} \\
\mathrm{M}-44-13 \mathrm{~A}^{4}\end{array}$ & $\begin{array}{l}9 / 30 / 1999 \\
7 / 15 / 1997\end{array}$ & $\begin{array}{l}\text { Draft WIRD for FY97 \& } \\
\text { FY98 }\end{array}$ & - & 1 & - & - \\
\hline & $\begin{array}{r}\mathrm{M}-44-00 \mathrm{~A} \\
\mathrm{M}-44-14 \mathrm{~A}^{4}\end{array}$ & $\begin{array}{l}9 / 30 / 1999 \\
8 / 31 / 1997 ? ?\end{array}$ & $\begin{array}{l}\text { Final WIRD for FY97 \& } \\
\text { FY98 }\end{array}$ & - & 1 & - & - \\
\hline & $\begin{array}{r}\mathrm{M}-44-00 \mathrm{~A} \\
\mathrm{M}-44-15 \mathrm{~A}^{4}\end{array}$ & $\begin{array}{l}9 / 30 / 1999 \\
9 / 30 / 1997\end{array}$ & $\begin{array}{l}\text { Letter - Completion of all } \\
\text { FY97 WIRD deliverables }\end{array}$ & - & 1 & - & - \\
\hline & $\begin{array}{r}M-44-00 A \\
M-44-16 A^{4}\end{array}$ & $\begin{array}{l}9 / 30 / 1999 \\
9 / 30 / 1997\end{array}$ & $\begin{array}{l}\text { Letter - Completion of all } \\
\text { FY97 data in electronic } \\
\text { database }\end{array}$ & - & 1 & - & - \\
\hline & $\begin{array}{r}\mathrm{M}-44-00 \mathrm{~A} \\
\mathrm{M}-44-13 \mathrm{~B}^{4}\end{array}$ & $\begin{array}{l}9 / 30 / 1999 \\
6 / 30 / 1998\end{array}$ & Draft WIRD for FY99 & - & - & - & 1 \\
\hline & $\begin{array}{r}\mathrm{M}-44-00 \mathrm{~A} \\
\mathrm{M}-44-14 \mathrm{~B}^{4}\end{array}$ & $\begin{array}{l}9 / 30 / 1999 \\
8 / 31 / 1998 ? ?\end{array}$ & Final WIRD for FY99 & - & - & - & 1 \\
\hline & $\begin{array}{r}\mathrm{M}-44-00 \mathrm{~A} \\
\mathrm{M}-44-15 \mathrm{~B}^{4}\end{array}$ & $\begin{array}{l}9 / 30 / 1999 \\
9 / 30 / 1998\end{array}$ & $\begin{array}{l}\text { Letter - Completion of all } \\
\text { FY98 WIRD deliverables }\end{array}$ & - & - & - & 1 \\
\hline
\end{tabular}


Table 6-1. Information Requirements Matrix. (10 sheets)

\begin{tabular}{|c|c|c|c|c|c|c|c|}
\hline$\frac{1}{4.6}$ & WRS Driver & (1.6. & Gialac & 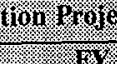 & S110po & & \\
\hline proguron or & Milistone & $\begin{array}{l}\text { Whitestone } \\
\text { Bue Bute }\end{array}$ & belinariole? & $\begin{array}{l}\text { romes } \\
\text { samples }\end{array}$ & frinis & 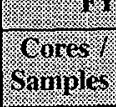 & 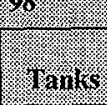 \\
\hline $\begin{array}{l}\text { Characterization } \\
\text { Planning } \\
\text { Deliverables } \\
\text { (Cont'd) }\end{array}$ & $\begin{array}{l}M-44-00 A \\
M-44-16 B^{4}\end{array}$ & $\begin{array}{l}9 / 30 / 1999 \\
9 / 30 / 1998\end{array}$ & $\begin{array}{l}\text { Letter - Completion of all } \\
\text { FY } 98 \text { data in electronic } \\
\text { database }\end{array}$ & - & - & - & 1 \\
\hline
\end{tabular}

Notes:

Dates are shown in $\mathrm{mm} / \mathrm{dd} / \mathrm{yy}$ format.

1 DNFSB Milestones all begin with "93-5". "93-" has been removed for brevity.

"Push Mode Sampling includes push mode sampling from both push mode and rotary mode trucks.

${ }^{3}$ FY98 Performance Agreement not yet completed

${ }^{4}$ Milestone rewritten, contract change order \#: M-44-97-03 
Table 6-2. Opportunistic ${ }^{1}$ Information Drivers. (2 sheets)

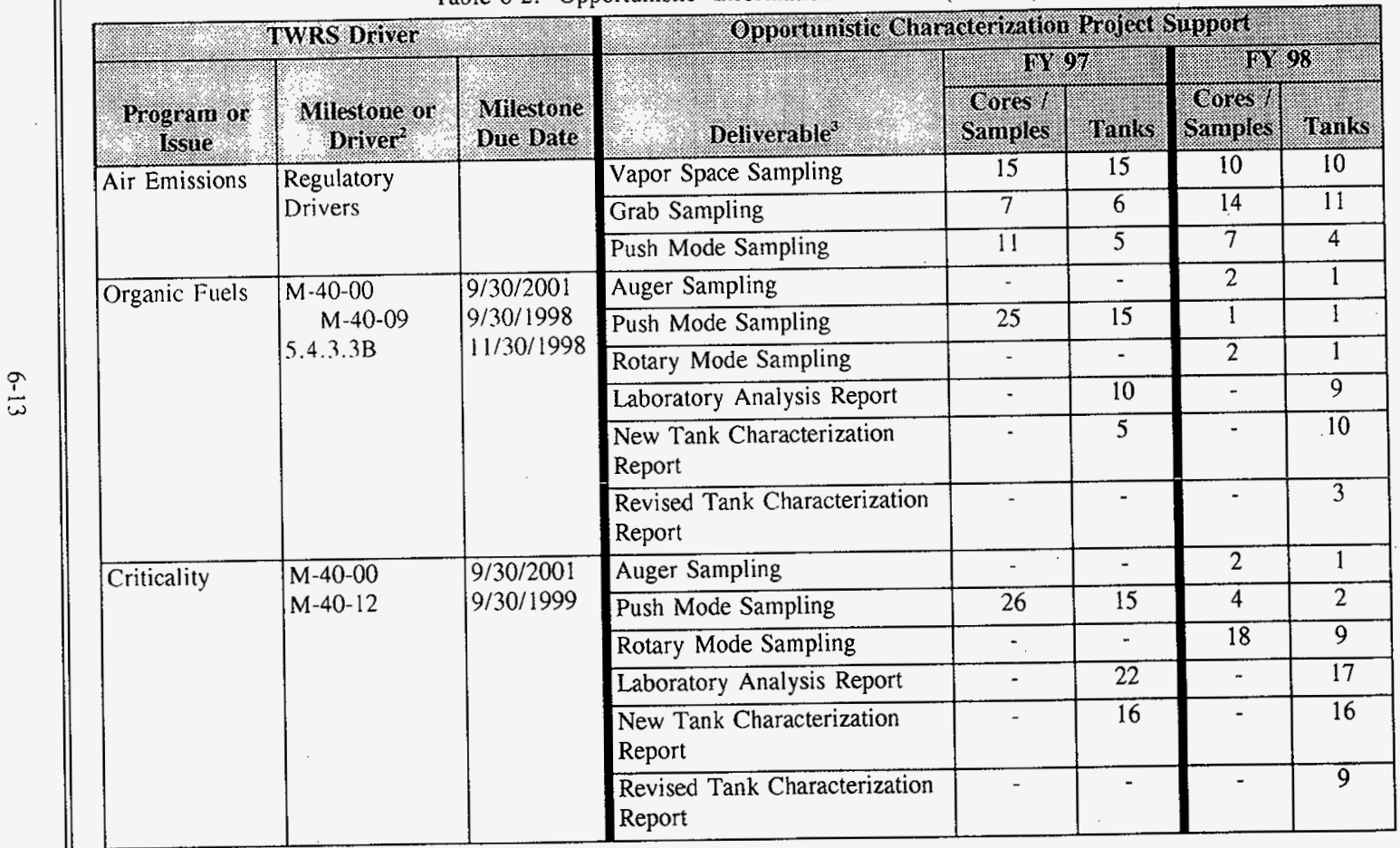



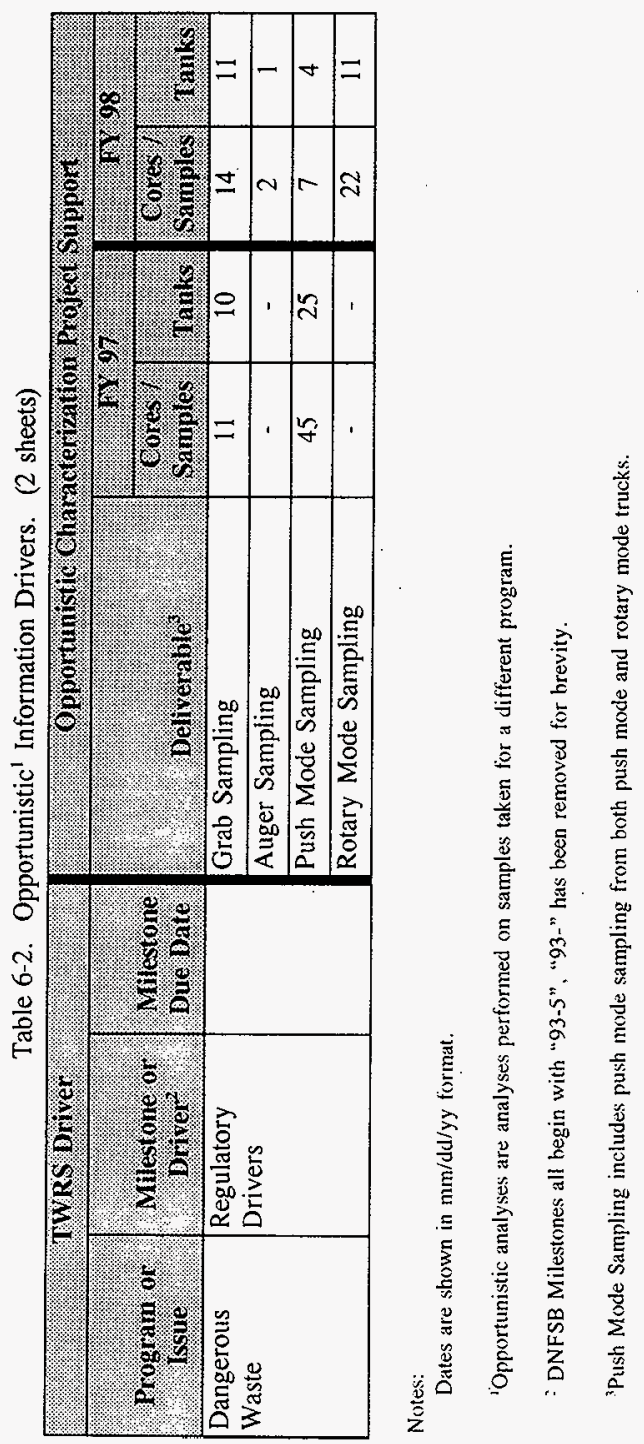


\subsection{SUMMARY DISCUSSION OF INFORMATION REQUIREMENTS}

Each Characterization Project activity supports a TWRS milestone. In many cases, one activity supports more than one issue. For this reason, the numbers in Tables 6-1 and 6-2 cannot be directly added. This section summarizes the numbers of each type of activity. More detailed information on each characterization activity is provided in Section 7.0.

\subsubsection{Summary Characterization Project Sampling Events}

Each tank may have a different number of each type of sample taken from it. For instance, vapor phenomenology studies require resampling of the same tank. In addition, caustic mitigation testing and retrieval operations require grab sampling the same tank several times. Table 6-3 summarizes the total number of tanks being sampled by sampling type and the total samples or events for each type of sampling.

Table 6-3. Summary of Characterization Project Sampling Events.

\begin{tabular}{|c|c|c|c|c|}
\hline 4 & & & & \\
\hline Iftivit Ther & $\begin{array}{l}\text { Cores! } \\
\text { Samples }\end{array}$ & Tanks & $\begin{array}{l}\text { Cores } \\
\text { Samples: }\end{array}$ & Tanis \\
\hline Push Mode (RGS) Sampling & 10 & 4 & 5 & 3 \\
\hline Push Mode Sampling & 35 & 21 & 2 & 1 \\
\hline Rotary Mode Sampling & - & - & $22^{1}$ & 11 \\
\hline Auger Sampling & - & - & 2 & 1 \\
\hline Grab Sampling & 11 & 10 & 14 & 11 \\
\hline Vapor Sampling & 48 & 25 & 14 & 14 \\
\hline LDUA Sampling & - & - & 1 & 1 \\
\hline
\end{tabular}

Note:

'Includes 1 core from a sampling event ending in FY98 completed by the end of FY97.

\subsubsection{Summary Characterization Reports}

Laboratory analysis reports and tank characterization reports are two types of reports that are closely associated with sampling events. After a tank is sampled, a laboratory report of analysis is issued and, in many cases, a tank characterization report will be created or updated. Table 6-4 lists a summary of Characterization Project reports scheduled for completion. 
Section 7.2 discusses other types of reports.

Table 6-4. Summary of Characterization Project Reports.

\begin{tabular}{|c|c|c|}
\hline Marity $10 \%$ & If 97 & \% 18 \\
\hline Grab Sample Based Laboratory Analysis Reports & 12 & 11 \\
\hline Core Based Laboratory Analysis Reports & 25 & 25 \\
\hline Vapor Analysis Reports & 33 & 16 \\
\hline New Tank Characterization Reports & 16 & 16 \\
\hline Revisions to TCR's & 23 & $10^{1}$ \\
\hline
\end{tabular}

Note:

'Represents number of tanks sampled in FY 97 and FY 98 which have existing TCRs. 


\subsection{DESCRIPTION OF CHARACTERIZATION PROJECT DELIVERABLES AND ACCEPTANCE CRITERIA}

Characterization Project deliverables that support the milestones listed in Section 6.0 are usually associated with the completion of a significant scope of work in the characterization process as described in Tank Waste Remediation System Process Engineering Instruction Manual (Adams 1997). These deliverables can also be categorized as a written report or the delivery of tank waste samples. The primary focus in acquiring characterization information for safety, disposal, and TWRS operations functions is to sample tanks, analyze samples, and interpret data obtained.

\subsection{CHARACTERIZATION PROJECT SAMPLING ACTIVITIES}

This section outlines the types of sampling performed by the Characterization Project and the issues associated with each type of sampling. In some cases, the sampling performed for one issue will also meet the information needs of another issue. These overlaps in sampling requirements will be noted below. This section also indicates the number of samples expected in Fiscal Years 1997 and 1998 for each type of sampling.

\subsubsection{Core Samples}

Core sampling provides a sample that represents the entire waste depth, regardless of whether the waste is in the liquid or solid phase. Core sampling may be performed in push mode or rotary mode. At this time, the RGS may only be used in push mode core sampling.

The organic complexant, safety screening, privatization, pretreatment, historical evaluation, and HTI issues use core sampling information and are not particular about the mode of sampling. Only the flammable gas safety program requires using RGS samples.

The number of core samples expected in Fiscal Years 1997 and 1998 is provided below for each mode of core sampling.

7.1.1.1 Push Mode Core Sampling (including RGS Sampling). Twenty-five tanks are expected to be push mode core sampled in Fiscal Year 1997, with 45 cores being taken in total. Ten cores from four tanks will be taken with the RGS sampler. In Fiscal Year 1998, four tanks will be push mode core sampled, with seven cores total being taken. Five cores from three tanks will be taken with the RGS sampler. 
7.1.1.2 Rotary Mode Core Sampling. In Fiscal Year 1997, no tanks will be sampled using the rotary mode sampling system. In Fiscal Year 1998, 11 tanks will be sampled using the rotary mode sampling system; two cores will be taken per tank for a total of 22 cores.

\subsubsection{Grab Sampling}

Grab sampling is used to take a liquid sample or a sample of salt or sludge solids that are suspended in a slurry in liquid. Grab sampling can take liquid samples from the surface of the tank or below the surface as long as there is no solid layer to obstruct the sampler.

Grab samples are used to satisfy requirements of the operations issues, particularly waste compatibility, evaporator operations, and caustic mitigation. Grab samples may also be used to provide privatization LAW samples to the private vendors. When no solid waste layers are expected, grab samples may be used to satisfy the sampling requirements of safety screening. Other specific grab sampling requirements include grab samples from tank 241-AY-102 after the sluicing of tank 241-C-106 and grab samples from tank 241-AZ-101 to support mixer pump testing.

Currently, 11 grab samples will be taken from 10 tanks in Fiscal Year 1997. In Fiscal Year 1998, 14 grab samples will be taken from 11 tanks.

\subsubsection{Vapor Sampling}

Vapor sampling is used to take a gas sample from inside the tank dome, above the surface of the solid or liquid waste. Past vapor sampling has used both the VSS and the ISVS. Future vapor sampling will use only the ISVS.

Vapor samples are used to satisfy requirements of the organic solvent safety issue and vapor space phenomenology studies. Vapor samples must also be taken for each tank that requires rotary-mode core sampling before core sampling. Vapor samples in rotary-mode tanks are taken to meet requirements outlined in the air emissions regulatory DQO.

Currently, 48 vapor samples are expected to be taken from 25 tanks in Fiscal Year 1997. In Fiscal Year 1998, 14 vapor samples are scheduled to be taken from 14 tanks.

\subsubsection{Auger Sampling}

Auger sampling involves manually drilling an auger into the waste surface to obtain a sample from the top of the waste (usually the top 25 to 30 inches). Auger sampling is not effective in dry, crumbly waste because the sample will not adhere to the auger or in liquids. Currently, no auger samples are scheduled in Fiscal Year 1997 and two auger samples from 
tank 241-AX-104 will be taken in Fiscal Year 1998 to support Hanford Tanks Initiatives objectives.

\subsubsection{Special Sampling}

Occasionally, a different type of sampling may be used in place of conventional methods. The only current example of nonconventional method involves the sampling of tank 241-AX-104 for the HTI program. Because the tank is almost empty, conventional solid and liquid phase samplers are not expected to work.

\subsection{CHARACTERIZATION PROJECT REPORTS}

Reports are the other major type of characterization deliverable. Reports generated by the characterization project and the Fiscal Years 1997 and 1998 projected delivery dates are described in this section.

\subsubsection{Laboratory Analysis Reports}

After a tank is sampled and data is analyzed, a laboratory analysis report is issued with the results of each type of sample (see Section 7:1). Laboratory analysis results document the recovery of the sample, the preparation methods used before analysis, the analyses performed, the results of the analyses, and the quality control standards applied. Laboratory analysis reports are directed by the sampling and analysis plans generated by the characterization project.

For the Characterization Project, laboratory analysis reports on solid or liquid samples are generated by the 222-S Laboratory. In Fiscal Year 1997, 25 laboratory analysis reports are expected to be produced for solid samples and 12 laboratory analysis reports for liquid samples. In Fiscal Year 1998, 25 laboratory analysis reports are expected to be produced for solid samples and 11 laboratory analysis reports for liquid samples.

In Fiscal Year 1997, laboratory analysis reports for the ISVS and the VSS vapor samples will be produced by Pacific Northwest National Laboratory and by Special Analytical Support (Numatec Hanford Corporation) for the Characterization Project. In Fiscal Year 1997, 33 vapor laboratory analysis reports are expected. In Fiscal Year 1998, laboratory analysis reports for the ISVS and VSS samples will be produced only by Special Analytical Support. Sixteen vapor laboratory analysis reports are expected in Fiscal Year 1998.

\subsubsection{Tank Characterization Reports}

A TCR has two primary functions. The first function is to report the results of the characterization performed for the DQO requirements. The DQO's represent the current 
tank characterization needs of TWRS programs. The second function is to report the Characterization Projects best evaluation of the inventory of chemical and radionuclide constituents within the waste. The TCR reports tank waste inventory by including the best basis inventory reports. In the future, acceptable TCRs will contain process knowledge, prior characterization data, and validated empirical data acquired after May 1989.

In Fiscal Year 1997, the Characterization Project expects to issue 39 TCRs; 16 will be based on new characterization information. The remaining 23 will update existing TCRs. In Fiscal Year 1998, 16 TCRs will be written; all will be based on new information, and 10 will be for tanks that currently have a TCR.

\subsubsection{Data Quality Objectives}

The data quality objectives (DQO) report is the outcome of the DQO process. The DQO process is a strategic planning approach based on the Scientific Method that is used to prepare a data collection activity. Programs such as Safety, Disposal, Privatization, or Environmental Compliance use the DQO process to define and formalize their data needs. Characterization then uses the resulting DQO information needs (as outlined in the DQO reports) to produce sampling and analysis plans.

Six DQO reports will be issued in Fiscal Year 1997 and three in Fiscal Year 1998.

\subsubsection{Historical Tank Content Estimates}

Characterization information can be obtained from HTCE. The primary function of HTCE reports is to document the results of the Hanford Defined Waste model of the tank waste contents produced by Los Alamos National Laboratory. A second function of the HTCE reports is to provide other tank information such as surveillance data, tank drawings and riser diagrams, and photographs taken of the waste surface.

The HTCE reports have been subdivided into two deliverables. The first deliverable is made up of supporting documents, a large collection of historical information. One supporting document is produced for each tank farm. The second deliverable is a summary of useful information collected from the supporting documents. The tank farms are grouped so that four HTCE reports cover all 18 tank farms.

In Fiscal Year 1997, the Characterization Project will deliver three summary reports and 12 supporting documents. No further deliverables of HTCE summaries or supporting documents will be provided in Fiscal Year 1998. 


\subsubsection{Best Basis Inventory Reports}

The Characterization Project documents its best evaluation of the contents of all tanks in best basis inventory reports. The best basis inventory evaluation is a documented study of all available information about the contents of the tanks. Current samples and historical information are used to produce the best basis inventory. The results of the best basis inventory are also reported in TCR reports.

In Fiscal Year 1997, 134 best basis inventory evaluations will be performed, thereby completing the evaluation for all 177 tanks. After Fiscal Year 1997, the best basis inventory and TCRs will be updated as more information becomes available.

\subsubsection{Vapor Space Phenomenology Reports}

Before vapor space samples can be used reliably, it was necessary to better understand tank vapor space. For this reason, two studies about tank vapor space phenomenolgy were performed. The first was the vapor space mixing study which addressed whether samples, collected from a single tank headspace location, represented headspace in general (that is, whether the headspace vapor was homogeneous). Sampling for the mixing study was completed in November, 1996: the results will be issued in Fiscal Year 1997.

The second study was the temporal study which addressed the extent to which vapor headspace composition changes over time. Sampling for the temporal study was completed in May, 1997; the results will be issued in Fiscal Year 1997.

\subsubsection{Tank by Tank Safety Evaluation}

In January 1997, a letter (Wagoner 1997) was sent to the DNFSB proposing a format for a tank-by-tank safety evaluation. The safety evaluation will report the outcome of sampling and analysis for the various safety DQOs. A report will be issued in Fiscal Year 1998 that provides tank-by-tank safety evaluations for all 177 tanks.

\subsubsection{High-Priority Tank Evaluation}

In the Recommendation 93-5 Implementation Plan, Revision 1 (DOE-RL 1996), 28 high-priority tanks were recommended for sampling. By sampling high-priority tanks first, it was expected that the resolution of the various safety issues and an increased knowledge of waste composition would occur. Several questions were addressed for each high-priority tank. The questions (Appendix J, DOE-RL 1996) will be addressed in High-Priority Tank Evaluation, a report to be issued by the Characterization Project in Fiscal Year 1998. 


\subsection{ACCEPTANCE CRITERIA FOR ECOLOGY DELIVERABLES}

\subsubsection{Waste Information Requirements Document}

The TWRS information needs shall be defined in a Waste Information Requirements Document (WIRD) to be submitted annually to Ecology. The document shall identify annual characterization deliverables to support safe storage, retrieval, and disposal of tank waste. The WIRD shall also identify, for approval, the tank waste behavior information needs for each subsequent year. The WIRD shall describe characterization deliverables to be issued for each year based on existing Tri-Party Agreement milestones and shall specify the content of each of the deliverables.

When other TWRS Program related tank waste characterization Tri-Party Agreement milestones are revised or modified via the Tri-Party Agreement change control process, the appropriate characterization deliverables shall be revised or modified at the end of each fiscal year to reflect the changes.

If WIRD revisions are required when program needs change or resource constraints develop, a revised WIRD shall be forwarded to Ecology with a letter for concurrence. The letter shall contain an explanation for the revisions.

That portion of the WIRD that identifies tank waste characterization activities outside of the scope of the Tri-Party Agreement (that is, Department of Energy Secretarial Initiatives, Defense Nuclear Facilities Safety Board Milestones) shall not be subject to Ecology approval or concurrence, but shall be included for informational purposes only.

The draft WIRD shall be submitted to Ecology on or before June 30 of each year. Ecology shall provide comments within 30 days after submittal. The final WIRD shall be submitted to Ecology on or before August 31 of each year. If the three parties do not agree on any individual deliverable then Ecology shall issue a final decision no later than September 30 of that year for the scope of the deliverable. U.S. Department of Energy, Richland Operations Office (DOE-RL) shall implement the final decision of Ecology. If DOE-RL disputes the final decision, Ecology's final decision shall be implemented during the dispute resolution process.

Each year the WIRD submittal to Ecology shall include an end of the fiscal year progress summary report. The tables within WIRD shall indicate the planned number of cores to be taken during each subsequent year. An acceptable level of performance shall be the historical recovery rate statistics for each core (sampling) methodology. 
The WIRD document shall meet the quality standards as defined in Uniform Publications System (WHC-CM-3-6). It shall contain standardized formats for tables and figures. Standardized text shall be used to the maximum extent practicable. An acceptable document shall include, but not be limited to, the following content:

- Introduction

- Background

- Scope

- Summary Report of Progress

- Review and Summary of Changes to Previous Edition

- TWRS Program Drivers Requiring Characterization Information

- TWRS Issues with Characterization Information Requirements

- Information Requirements Matrix

- Description of Characterization Project Deliverables

- Acceptance Criteria

- References.

\subsubsection{Tank Characterization Reports}

Tank characterization reports constitute the second deliverable to Ecology. Information in the TCRs shall be placed into an electronic database accessible to Ecology within seven business days after completion of the Laboratory Analysis Report (for analytical data) or by 7 days after publication of the final TCR (for inventory and historical data.) The TCRs shall meet the quality standards as defined in WHC-CM-3-6. TCRs shall use standardized formats for tables and figures. Standardized text shall be used to the greatest possible extent. The TCRs shall contain but shall not be limited to the content described in the Tank Waste Remediation System Process Engineering Instruction Manual (Adams 1997). 
This page intentionally left blank. 


\subsection{REFERENCES}

Adams, M. R., 1997, TWRS Process Engineering Instruction Manual,

HNF-SD-WM-PROC-021, Rev. 0C, Lockheed Martin Hanford Corporation, Richland, Washington.

Agnew, S. F., 1996, History of Organic Carbon in Hanford HLW Tanks: HDW Model, Rev. 3, LA-UR-96-989, Los Alamos National Laboratory, Los Alamos, New Mexico.

Agnew, S. F., J. Boyer, R. A. Corbin, T. B. Duran, J. R. FitzPatrick, K. A. Jurgensen, T. P. Ortiz, and B. L. Young, 1997, Hanford Tank Chemical and Radionuclide Inventories: HDW Model, Rev. 4, LA-UR-96-3860, Los Alamos National Laboratory, Los Alamos, New Mexico.

Barney, G. S., 1996, The Solubilities of Significant Organic Compounds in HLW Tank Supernatant Solutions - FY 1996 Progress Report, WHC-EP-0899-1, Westinghouse Hanford Company, Richland, Washington.

Bloom, G. R. and Q. H. Nguyen, 1996, Characterization Data Needs for Development, Design and Operation of Rerrieval Equipment Developed through the Data Quality Objective (DQO) Process, WHC-SD-DQO-008, Rev. 1, Westinghouse Hanford Company, Richland, Washington.

Brown, T. M., J. W. Hunt, and L. J. Fergestrom, 1997, Tank Characterization Technical Sampling Basis, HNF-SD-WM-TA-164, Rev. 3, Lockheed Martin Hantord Company, Richland, Washington.

Buckley, L. L., 1997, Vapor Sampling and Analysis Plan/Test Plan for Temporal Studies of Tanks $B X-104, B Y-108, C-107$ and S-102, WHC-SD-WM-TP-522, Rev. OD, Lockheed Martin Hanford Corporation, Richland, Washington.

Buckley, L. L., 1996, Vapor Sampling and Analysis Plan for Headspace Homogeneiny Tests of Tanks B-103, TY-103, and U-112, WHC-SD-WM-TSAP-114, Rev. OD, Lockheed Martin Hanford Corporation. Richland. Washington.

Camaioni, D. M., W. D. Samuels, J. C. Linehan, S. A. Clauss, A. K. Sharma, K. L. Lahl, and J. A. Campbell, 1996, Organic Tanks Safery Program FY 1996 Waste Aging Studies, PNNL-11312, Pacific Northwest National Laboratory, Richland, Washington.

Cash, R. J., 1996a, Applicarion of "Flammable Gas Tank Safery Program: Data Requirements for Core Sampling Analysis Developed Through the Data Quality Objectives Process," Rev. 2, (internal memo 79300-96-028 to S. J. Eberlein, July 12), Westinghouse Hanford Company, Richland, Washington. 
Cash, R. J., 1996b, Scope Increase of "Data Quality Objective to Support Resolution of the Organic Complexant Safety Issue," Rev. 2 (internal memorandum \#79300-96-029, to S. J. Eberlein, July 12), Westinghouse Hanford Company, Richland, Washington.

Certa, P. J., C. N. McConville, L. W. Shelton, and E. J. Slaathaug, 1996, Preliminary Low-Level Waste Feed Staging Plan, WHC-SD-WM-RPT-210, Rev. 0, Westinghouse Hanford Company, Richland, Washington.

Conway, J. T., 1993, Hanford Waste Characterization Studies, DNFSB Recommendation 93-5, Defense Nuclear Facilities Safety Board, Washington, District of Columbia.

DOE-RL, 1996, Recommendation 93-5 Implementation Plan, DOE-RL 94-0001, Rev. 1, Change 2, U.S. Department of Energy, Richland Operations Office, Richland, Washington.

Dukelow, G. T., J. W. Hunt, H. Babad, and J. E. Meacham, 1995, Tank Safery Screening Data Quality Objective, WHC-SD-WM-SP-004, Rev. 2, Westinghouse Hanford Company, Richland, Washington.

East and West Tank Farms, 1997, Compensatory Actions for Open Discovery Unreviewed Safety Questions (USQs), Standing Order 97-01, Lockheed Martin Hanford Corporation, Richland, Washington.

Ecology, EPA, and DOE, 1996, Hanford Federal Facility Agreement and Consent Order, as amended, Washington State Department of Ecology, U.S. Environmental Protection Agency, and U.S. Department of Energy. Olympia, Washington:

EPA, 1994, Guidance For The Data Quality Objectives Process, EPA QA/G-4, U.S. Environmental Protection Agency, Washington, D. C.

Fowler, K. D., 1995, Data Quality Objectives for Tank Farms Waste Compatibility Program, WHC-SD-WM-DQO-001, Rev. 1, Westinghouse Hanford Company, Richland, Washington.

Hall, L. E., 1997, Status on Approach to Managing Tank Waste Remediation Systems Tank Waste Feed Staging, Retrieval Sequence, and Space Projection Activities, (letter to D. J. Washenfelder, 96-02829BR5, February 5). Lockheed Martin Hanford Corporation, Richland, Washington.

Jensen, L., and F. R. Reich, 1997, Statistical Techniques for Characterization of Residual Waste in Single-Shell and Double-Shell Tanks, HNF-SD-WM-TI-799, Rev. 0, Numatec Hanford Corporation, Richland, Washington. 
Jones, T. E., K. D. Wiemers, 1996, Data Requirements for TWRS Privatization Characterization of Potential Low Activity, Waste Feed, WHC-SD-WM-DQO-023, Rev. 0, Westinghouse Hanford Company, Richland, Washington.

Kupfer, M. J., W. W. Schulz, and J. T. Slankas, 1995, Strategy for Sampling Hanford Site Tank Wastes for Development of Disposal Technology, WHC-SD-WM-TA-154, Rev. 1, Westinghouse Hanford Company, Richland, Washington.

Laws, G. L., 1996, Status of the Current Understanding of the Toxic Air Pollutants (TAPS) and Hanford Tank Farm Vapor Space Characterization; Recommended Path Forward and Justification for Continued RMCS Exhauster Operations, (telephone conference memorandum 01830-96-022 to Distribution, March 8), Westinghouse Hanford Company, Richland, Washington.

LHMC, 1996, Operating Specificarions for the $124-A N, A P, A W, A Y, A Z$, and $S Y$ Tank Farms, OSD-T-151-00007, Rev. H-18, Lockheed Martin Hantord Corporation, Richland, Washington.

Lumetta, G. J., and B. M. Rapko, 1994, Washing and Alkaline Leaching of Hanford Tank Sludges: A Status Repon, PNL-10078. Pacific Northwest National Laboratory, Richland, Washington.

Lumetta, G. J., M. J. Wagner, R. J. Barrington, B. M. Rapko, and C. D. Carlson, 1994, Sludge Treatment and Extraction Technology Development: Results of FY 1993 Studies, PNNL-9387, Pacific Northwest National Laboratory, Richland, Washington.

Lumetta, G. J., B. M. Rapko, M. J. Wagner, J. Liu, Y. L. Chen, 1996, Washing and Caustic Leaching of Hanford Tank Sludges: Results of FY 1996 Studies, PNNL-11278, Rev. 1, Pacific Northwest National Laboratory, Richland, Washington.

Mahon, R. D., C. M. Jones, and M. S. Story, 1994, Evaluation of the Capabilities and Use of the Vapor Sampling System for Tank Headspace Sampling and Characterization, WHC-SD-WM-RPT-094. Rev. 0. Westinghouse Hantord Company, Richland, Washington.

Manuel, A. F., 1996, Phase One High-Level Waste Pretreatment and Feed Staging Plan, WHC-SD-WM-ES-370, Rev. 0, Westinghouse Hanford Company, Richland, Washington.

McDuffie, N. G., 1995, Flammable Gas Tank Safety Program: Data Requirements for Core Sample Analysis Developed Through the Data Quality Objectives (DQO) Process, WHC-SD-WM-DQO-004, Rev. 2, Westinghouse Hanford Company, Richland, Washington. 
Meacham, J. E., 1996a, Implementation Change Concerning Organic DQO, Rev. 2, (internal memorandum 2N160-96-006 to distribution, December 2), Duke Engineering \& Services Hanford, Richland, Washington.

Meacham, J. E., 1996b, Increase Scope to Organic $D Q O$, (internal memorandum 2N160-96-003 to J. G. Kristofszki, October 31), Duke Engineering \& Services Hanford, Richland, Washington.

Mulkey, C. H., and K. D. Markillie, 1995, Data Quality Objective for Regulatory Requirements for Hazardous and Radioactive Air Emissions Sampling and Analysis, WHC-SD-WM-DQO-021, Rev. 0, Westinghouse Hanford Company, Richland, Washington.

Mulkey, C. H., 1996, Data Quality Objectives for Regulatory Requirements for Dangerous Waste Sampling and Analysis, WHC-SD-WM-DQO-025, Rev. 0, Westinghouse Hanford Company, Richland, Washington.

Osborne, J. W., and L. L. Buckley, 1995, Data Quality Objectives for Tank Hazardous Vapor Safety Screening, WHC-SD-WM-DQO-002, Rev. 2, Westinghouse Hanford Company, Richland, Washington.

Price, D. N., 1994, Rotary Core Vapor Sampling Data Quality Objective, WHC-SD-WM-SP-003, Rev. 0, Westinghouse Hanford Company, Richland, Washington.

Rapko, B. M., G. J. Lumetta, and M. J. Wagner, 1995, Washing and Caustic Leaching of Hanford Tank Sludges: Results of FY 1995 Studies, PNL-10712, Pacific Northwest Laboratory, Richland, Washington.

Schreiber, R. D., 1997, Fiscal Year 1997 Memorandum of Understanding for the TWRS Characterization Project, HNF-SD-WM-SD-023, Rev. 0., Lockheed Martin Hanford Corporation, Richland, Washington.

Sieracki, S. A., 1997. Contract Number DE-AC06-96RL13200 - Directed Change For Characterization Project To Develop a Proposed Change to the Hanford Federal Facility Agreement and Consent Order (Tri-Parn: Agreement), M-44-00 Milestone, (letter 97-WSD-093 to H. J. Hatch, April 17). Department of Energy, Richland Operations Office, Richland Washington.

Simpson, B. C., and D. J. McCain, 1997, Historical Model Evaluation Data Requirements, WHC-SD-WM-DQO-018, Rev. 2, Westinghouse Hanford Company, Richland, Washington. 
Stahl, S. M., 1997, Hanford Site Tank Farm Facilities Interim Safety Basis, WHC-SD-WM-ISB-001, Rev. OM, Westinghouse Hanford Company, Richland, Washington.

Slankas, T. J., M. J. Kupfer, and W. W. Schulz, 1995, Data Needs and Attendant Data Quality Objectives for Tank Waste Pretreatment and Disposal, WHC-SD-WM-DQO-022, Rev. 0, Westinghouse Hanford Company, Richland, Washington.

Temer, D. J., and R. Villatreal, 1995a, Sludge Washing and Alkaline Leaching Tests on Actual Hanford Tank Sludge: A Draft Report on Samples TY-104 and C-107, LAUR-95-3211, Los Alamos National Laboratory, Los Alamos, New Mexico.

Temer, D. J., and R. Villarreal, 1995b, Sludge Washing and Alkaline Leaching Tests on Actual Hanford Tank Sludge: A Status Report, LAUR-95-2070, Los Alamos National Laboratory, Los Alamos, New Mexico.

Temer, D. J., and R. Villarreal, 1996, Sludge Washing and Alkaline Leaching Tests on Actual Hanford Tank Sludges: FY 1996 Results, LAUR-96-2839, Los Alamos National Laboratory, Los Alamos, New Mexico.

Turner, D. A., H. Babad, L. L. Buckley, and J. E. Meacham, 1995, Data Quality Objective to Support Resolution of the Organic Complexant Safety Issue, WHC-SD-WM-DQO-006, Rev. 2, Westinghouse Hantord Company, Richland, Washington.

Umek, A. M., 1997, Subcontract Number 80232764-9-K001; Directed Change to the Hanford Federal Faciliry Agreement and Consent Order M-44-00 Milestone, (letter FDH-9753729A to L. E. Hall. April 30). Fluor Daniel Hantord. Richland. Washington.

Von Bargen, B. H., 1995, 242-A Evaporator/Lituid Effluem Retemion Facility Data Quality Objectives, WHC-SD-WM-DQO-014. Rev. 1. Westinghouse Hanford Company, Richland, Washington.

Wagoner, J. D., 1997. Completion of Defense Nuclear Facilitiex Safery Board (DNFSB) Recommendation 93-5 Implementarion Plan (IP). Revision 1. Milestone 5.6.3.1C, Letter Reporting Submitral of Proposed Content and Format for Tank-by-Tank Status Evaluation, (letter to J. T. Conway, DNFSB, January 30). Department of Energy. Richland Operations, Richland, Washington.

WHC-CM-3-6, Uniform Publication System, Westinghouse Hanford Company, Richland, Washington. 
DOE/RL-97-76 Rev. 0

This page intentionally left blank. 
DOE/RL-97-76 Rev. 0

APPENDIX A

TRI-PARTY AGREEMENT NUMBERS AND TITLES 
DOE/RL-97-76 Rev. 0

This page intentionally left blank. 


\section{APPENDIX A}

\section{TRI-PARTY AGREEMENT NUMBERS AND TITLES}

M-40-00 MITIGATE/RESOLVE TANK SAFETY ISSUES FOR HIGH PRIORITY WATCH LIST TANKS

M-40-09 CLOSE ALL UNREVIEWED SAFETY QUESTIONS FOR DOUBLE-SHELL \& SINGLE-SHELL TANKS

M-40-12 NUCLEAR CRITICALITY SAFETY ISSUE RESOLVED

M-41-00 COMPLETE SINGLE-SHELL TANK INTERIM STABILIZATION

M-41-21 START INTERIM STABILIZATION OF 2 SSTS

M-41-22 Start Interim Stabilization of SIX (6) Single-Shell Tanks

M-41-23 START INTERIM STABILIZATION OF EIGHT (8) SINGLE-SHELL TANKS

M-41-24 START INTERIM STABILIZATION OF NINE (9) SINGLE-SHELL TANKS

M-44-00A COMPLETE DELIVERY OF INFORMATION REQUIREMENTS AS IDENTIFIED IN THE ANNUALLY SUBMITTED WIRD

M-44-13A SUBMIT DRAFT WIRD TO ECOLOGY FOR FISCAL YEARS (FY) 1997 AND 1998

M-44-13B SUBMIT DRAFT WIRD TO ECOLOGY FOR FY 1999

M-44-15A SUBMIT FINAL WIRD FOR FY 1997 AND FY 1998 TO ECOLOGY

M-44-15B SUBMIT FINAL WIRD FOR FY 1999 TO ECOLOGY

M-44-17A ISSUE CHARACTERIZATION DELIVERABLES CONSISTENT WITH WIRD DEVELOPED FOR FY 1997

M-44-17B ISSUE CHARACTERIZATION DELIVERABLES CONSISTENT WITH WIRD DEVELOPED FOR FY 1998 
M-44-18A COMPLETE INPUT OF CHARACTERIZATION INFORMATION FOR HLW TANKS FOR WHICH SAMPLING AND ANALYSIS WERE COMPLETED PER WIRD, INTO AN ELECTRONIC DATABASE. OFF-SITE ACCESS TO THE DATABASE CONTAINING TANK WASTE CHARACTERIZATION INFORMATION WILL BE MADE AVAILABLE TO THE ENVIRONMENTAL PROTECTION AGENCY AND THE WASHINGTON STATE DEPARTMENT OF ECOLOGY

M-44-18B COMPLETE INPUT OF CHARACTERIZATION INFORMATION FOR HLW TANKS FOR WHICH SAMPLING AND ANALYSIS WERE COMPLETED PER WIRD, INTO AN ELECTRONIC DATABASE. OFF-SITE ACCESS TO THE DATABASE CONTAINING TANK WASTE CHARACTERIZATION INFORMATION WILL BE MADE AVAILABLE TO THE ENVIRONMENTAL PROTECTION AGENCY AND THE WASHINGTON STATE DEPARTMENT OF ECOLOGY

M-45-00 COMPLETE.CLOSURE OF ALL SINGLE SHELL TANK FARMS

M-45-03A INITIATE SLUICING RETRIEVAL OF C-106

M-45-06-T01 SUBMIT TANK CLOSURE/POST-CLOSURE PLAN FOR SELECTED CLOSURE DEMONSTRATION OPERABLE UNIT OR TANK FARM TO ECOLOGY FOR APPROVAL

M-50-00 COMPLETE PRETREATMENT PROCESSING OF HANFORD TANK WASTE

M-50-03 COMPLETE EVALUATION OF ENHANCED SLUDGE WASHING TO DETERMINE WHETHER ADVANCED SLUDGE SEPARATION PROCESSES ARE REQUIRED

M-50-03-T2C SUBMIT A REPORT SUMMARIZING THE TESTING OF ENHANCED SLUDGE WASHING \& RELATED TANK WASTE SLUDGE PRETREATMENT METHODS FOR SAMPLES OF TANK WASTE SLUDGE

M-51-00 COMPLETE VITRIFICATION OF HANFORD HIGH LEVEL TANK WASTE

M-60-00 COMPLETE PRETREATMENT AND IMMOBILIZATION OF HANFORD LOW ACTIVITY TANK WASTE (LAW)

M-60-10 SELECT TWO (2) COCO CONTRACTORS AND ISSUE DOE SIGNED AUTHORIZATIONS TO PROCEED WITH PART.B IAS DEFINED IN THE REQUEST FOR PROPOSAL /RFP/OR SUBSEQUENTLY NEGOTIATED CONTRACTS) WORKS FOR LAW PRETREATMENT AND IMMOBILIZATION. 
M-60-11 START OF CONSTRUCTION FOR TWO (2) PHASE I LAW PRETREATMENT AND IMMOBILIZATION FACILITIES.

M-60-12 START HOT OPERATIONS OF TWO (2) COCO PHASE I LAW PRETREATMENT AND IMMOBILIZATION FACILITIES. 
DOE/RL-97-76 Rev. 0

This page intentionally left blank. 
DOE/RL-97-76 Rev. 0

APPENDIX B

DEFENSE NUCLEAR FACILITIES SAFETY BOARD

MILESTONE NUMBERS AND TITLES 
DOE/RL-97-76 Rev. 0

This page intentionaily left blank. 


\section{APPENDIX B}

\section{DEFENSE NUCLEAR FACILITIES SAFETY BOARD MILESTONE NUMBERS AND TITLES}

Milestones Supported by the Characterization Project

5.4.3.2A TRANSMIT TOPICAL REPORT ON RESOLUTION OF FERROCYANIDE SAFETY ISSUE TO DNFSB

5.4.3.3A TRANSMIT LETTER REPORTING COMPLETION OF SUPPORTING TECHNICAL DOCUMENT ON ORGANIC COMPLEXANT SAFETY ISSUE TO DNFSB

5.4.3.3B TRANSMIT LETTER REPORTING RESULTS OF TESTING COMPLETION (USING REAL WASTE SAMPLES) TO CONFIRM SAFE STORAGE CRITERIA, AND ORGANIC SOLUBILITY AND AGING EFFECTS ON FUEL CONTENT TO DNFSB

5.4.3.4A TRANSMIT LETTER REPORTING COMPLETION OF SAFETY ASSESSMENT COVERING POOL AND ENTRAINED ORGANIC SOLVENT FIRES TO DNFSB

5.4.3.4B TRANSMIT LETTER REPORTING COMPLETION OF ORGANIC SPECIATION OF CORE/AUGER SAMPLES FOR BY-108, BY-110, AND C-LO2 TO DNFSB

5.4.3.4C TRANSMIT LETTER REPORTING COMPLETION OF SUPPORTING TECHNICAL DOCUMENT FOR ORGANIC SOLVENT SAFETY ISSUE TO DNFSB

5.4.3.5G TRANSMIT LETTER REPORTING COMPLETION OF FLAMMABLE GAS SAFETY SCREENING OF REMAINING PASSIVELY VENTILATED SST'S TO DNFSB

5.4.3.5H TRANSMIT LETTER REPORTING COMPLETION OF SUPPORTING TECHNICAL DOCUMENT ON FLAMMABLE GAS SAFETY ISSUE TO DNFSB

5.4.3.5K TRANSMIT LETTER REPORTING COMPLETION OF RETAINED GAS SAMPLING IN TANKS AW-10I, AN-103, AN-104, AN-105 AND A-101 TO DNFSB 
5.4.3.5L TRANSMIT LETTER REPORTING REFINEMENT OF FLAMMABLE GAS GENERATION/RETENTION MODELS USING VOID METER AND RGS DATA TO DNFSB

5.4.3.6A TRANSMIT LETTER REPORTING COMPLETION OF TANK C-106 SUPERNATANT SAMPLING AND ANALYSIS TO DNFSB

5.4.3.6B TRANSMIT LETTER REPORTING COMPLETION OF TANK C-106 SAFETY ASSESSMENT TO DNFSB

5.4.3.6C TRANSMIT LETTER REPORTING INITIATION OF TANK C-106 WASTE RETRIEVAL TO DNFSB

5.4.3.6D TRANSMIT LETTER REPORTING COMPLETION OF TOPICAL REPORT TO RESOLVE HIGH HEAT SAFETY ISSUE TO DNFSB

5.4.3.7A TRANSMIT LETTER REPORTING COMPLETION OF TOPICAL REPORT TO RESOLVE THE CRITICALITY SAFETY ISSUE TO DNFSB

5.5.6.1A TRANSMIT LETTER REPORTING COMPLETION OF SAMPLING AND ANALYSIS OF HIGH PRIORITY TANKS FOR DISPOSAL PROGRAM TO DNFSB

5.6.3.1.B DOE-RL LETTER TO DNFSB REPORTING IMPLEMENTATION OF FTIR MOISTURE ANALYSIS CAPABILITY IN 222-S LABORATORY

5.6.3.1.C DOE-RL LETTER TO DNFSB REPORTING SUBMITTAL OF PROPOSED CONTENT AND FORMAT FOR TANK-BY-TANK SAFETY STATUS EVALUATION

5.6.3.1.D DOE-RL LETTER TO DNFSB REPORTING UPDATES TO THE HISTORICAL TANK CONTENT ESTIMATES

5.6.3.1.E DOE-RL LETTER TO DNFSB REPORTING VERIFICATION OF HEADSPACE HOMOGENEITY AND EVALUATION IN HEADSPACE VAPOR CONCENTRATIONS IN PASSIVELY VENTILATED TANKS WITH CHANGING ATMOSPHERIC TEMPERATURES

5.6.3.1.F DOE-RL.LETTER TO DNFSB REPORTING COMPLETION OF STANDARD INVENTORY ESTIMATES FOR ALL TANKS

5.6.3.1.G DOE-RL LETTER TO DNFSB REPORTING COMPLETION OF TANK CHARACTERIZATION BASIS (BROWN ET AL. 1995) HIGH PRIORITY TANKS SAMPLING AND ANALYSIS 
DOE/RL-97-76 Rev. 0

5.6.3.1.H DOE-RL LETTER TO DNFSB REPORTING COMPLETION OF TANK-BY-TANK SAFETY STATUS EVALUATION

5.6.3.1.I DOE-RL LETTER TO DNFSB REPORTING UPDATES TO THE TANK CONTENT MODELS OR DEFINE LIMITATIONS OF THE MODELS

5.6.3.1.J DOE-RL LETTER TO DNFSB REPORTING COMPLETION OF CORE SAMPLING OF ALL TANKS 
DOE/RL-97-76 Rev. 0

This page intentionally left blank. 


\section{DISTRIBUTION}

Number of copjes

\section{ONSITE}

1

3
U.S. Department of Energy-

Richland Operations office

Public Reading Room H2-53

Lockheed Mart in Hanford Corporation

R2-12

R2-12

S7-21

R2-12

R2-12

RI-10

A3-88

A3-89

A3-94 


\section{THIS PAGE INTENTIONALIY IEFT BLANK}

